\title{
Measurement of Investment Potential and Spatial Distribution of Arable Land among Countries within the "Belt and Road Initiative"
}

\author{
Yameng Wang ${ }^{+}{ }^{\mathbb{D}}$, Apurbo Sarkar ${ }^{+} \mathbb{D}$, Linyan Ma, Qian Wu and Feng Wei * \\ College of Economics and Management, Northwest A and F University, Yangling 712100, China; \\ wym@nwafu.edu.cn (Y.W.); apurbo@nwafu.edu.cn (A.S.); malinyan@nwafu.edu.cn (L.M.); \\ wuqian1803@nwafu.edu.cn (Q.W.) \\ * Correspondence: weifeng@nwsuaf.edu.cn; Tel.: +86-156-843-43120 \\ + These authors contributed equally to the study.
}

check for updates

Citation: Wang, Y.; Sarkar, A.; Ma, L.; Wu, Q.; Wei, F. Measurement of Investment Potential and Spatial Distribution of Arable Land among Countries within the "Belt and Road Initiative". Agriculture 2021, 11, 848. https://doi.org/10.3390/ agriculture 11090848

Academic Editor: Giuseppe Timpanaro

Received: 30 July 2021

Accepted: 2 September 2021

Published: 5 September 2021

Publisher's Note: MDPI stays neutral with regard to jurisdictional claims in published maps and institutional affiliations.

Copyright: (C) 2021 by the authors. Licensee MDPI, Basel, Switzerland. This article is an open access article distributed under the terms and conditions of the Creative Commons Attribution (CC BY) license (https:/ / creativecommons.org/licenses/by/ $4.0 /)$.

\begin{abstract}
The belt and road initiative (BRI) is a mutual development approach projected by China, which delivers exceptional opportunities for multi-phased communication and cooperation across Asia, Africa, and Europe. It opens ample opportunities for China to easily invest in overseas arable land. Based on the macro data of 119 countries in 2010 and 2016 before and after the BRI, the study comprehensively uses fuzzy C-means clustering and the entropy method to evaluate the potential of arable land investment from four dimensions, which existing literature has not fully grasped. Moreover, the study uses the exploratory spatial data analysis methods (ESDA), kernel density estimation, and trend surface analysis to study the spatial pattern characteristics. The results show that: (i) there are noticeable regional differences in the investment potential of arable land in BRI countries. Asian countries, led by Kazakhstan and Indonesia, and African Unions, led by Ethiopia, South Africa, and Tanzania, generally have higher investment potential. However, South America and European countries are relatively lower. (ii) Resource endowment and production conditions significantly impact overseas arable land investment potential. Asia and Africa have advantages in resource endowment and production conditions, while European countries generally have better economic and political environments. (iii) From the perspective of time evolution, the investment potential in 2016 is generally higher than in 2010, and the negative correlation and dispersion are lower than in 2010. Based on these findings, it is recommended that Chinese enterprises should comprehensively consider the differences in resource endowments and agricultural development levels in various countries, optimize investment layout, and reduce investment risks. Chinese companies should collaborate with host nations on modernization and promote the long-term viability of arable land investments.
\end{abstract}

Keywords: overseas arable land investment; potential measuring; spatial differentiation pattern; fuzzy C-means clustering; belt and road initiatives

\section{Introduction}

China's initiatives to support its rapidly expanding populations (1.398 billion in 2019) have long been acknowledged. Despite having roughly one-fifth of the global agricultural territory (approximately 167.5 million hectares), it serves over one-fifth of the global population [1,2]. Since the reform and opening up, China has made significant achievements in agricultural development, becoming the world's largest food producer and achieving the food security goal of basic self-sufficiency in grains and absolute security in the ration $[3,4]$. However, reducing available arable land resources, the decline of arable land quality, and the slow growth rate of grain yield have also caused China to rely heavily on imports to ensure national food security [2,5]. In 2020, China imported 115.55 million tons of agricultural products, a 944.8 percent increase from 1996 [6]. At the same time, 
the evolution of the international food trade pattern occurred, along with the increasingly technical and environmental barriers of various countries [7-9]. Moreover, the spread of the new coronavirus pneumonia (COVID-19) has resulted in global grain stocks falling to the lowest level of 611 million tons in 5 years [10,11], and some countries began to ban the export of agricultural products to protect themselves, which also putting's food trade in a disadvantageous position [12].

The Central Committee of the Communist Party of China articulated the No. 1 Central Document in 2019, which focuses on accelerating and supporting agricultural outreach, strengthening international cooperation in agriculture under the belt and road initiatives, and improving agricultural cooperation with foreign countries [13]. Seemingly, the No. 1 Central Document in 2020 (China No.1 Central Document of 2020 laying down Opinions of the Central Committee of Communist Party and the State Council of China on Doing a Good Job in the Key Areas of Agriculture, Rural Areas, and Farmers to Ensure the Building of a Moderately Prosperous Society in All Respects) focuses on food security, making it a priority to accelerate agricultural modernization by supporting enterprises to integrate into the global agricultural supply chain and enhance the ability to guarantee food supply [14]. The BRI-listed countries that are the most crucial cereal production areas globally account for more than $40 \%$ of the world's total cereal output [15]. They have rich agricultural resources, more untapped arable land, and massive investment potential [16]. Investment in arable land in these countries has gradually become an essential means of increasing China's agricultural product supply and ensuring national food security [17]. The nation's experience eliminating hunger in the country, where arable land and water resources are scarce, sets an example for other developing countries. China's skills and competence in producing, processing, storing, distributing, and trading are broadly shared wherever demanded [18]. As of the end of 2017, China's overseas agriculture investment reached 17.3 billion USD, establishing 851 enterprises in more than 100 countries and employing 134,000 local staff [19]. More sharing is made possible by further investments under the belt and road framework.

However, due to information asymmetry and the absence of risk management, cases of failures of Chinese companies' overseas arable investment projects continue to appear, which caused huge costs and hard lessons [20,21]. According to the "Status and Survey Report on Chinese Enterprises' Outbound Investment (2019)", the most challenging issue in the process of foreign investment by enterprises is the unstable political situation in the host country $(54.8 \%)$, while labor $(31 \%)$ and taxation $(25.9 \%)$ make up other major issues. Meanwhile, several issues such as export control and economic sanctions (25.9\%) and environmental protection (21.5\%) have also become essential challenges for Chinese companies to "go global". Therefore, constructing an indicator system consistent with Chinese companies' actual investment status and accurately assessing the investment potential of arable land in the host countries and regions suitable for Chinese companies to invest in has become a vital issue. This will also be useful for them to effectively respond to overseas investment challenges and reduce overseas investment risks.

Overseas arable land investment potential refers to the ability of certain countries or regions to attract foreign direct investment and is a comprehensive characterization of the regional agricultural investment environment and the degree of merit of arable land investment value [22]. It is the essential driving force determining whether transnational agricultural capital flows can be constituted spatially [23]. Some scholars believe that the investment potential of arable land depends on two factors: one is the amount of arable land-related resources, and the other is the quality of the investment environment [24]. However, other scholars have found that most host countries have low economic and rich arable resources [3]. Hussain et al. [25] used the entropy-based the Technique for Order of Preference by Similarity to Ideal Solution (TOPSIS) method to comprehensively assess China's overseas investment risks and natural resource potential in 63 BRI countries. They indicated that most Central and Eastern European countries and Singapore, Malaysia, Nepal, Bhutan, Russia, and countries such as Armenia and the UAE are the best choices 
for Chinese companies to invest overseas. Tian et al. [26] analyzed China's arable land investment data in 40 overseas countries from 2008 to 2018 and found that China's overall economic strength has significantly increased overseas arable land investment. Resource endowments and labor costs have positively impacted overseas arable investment by Chinese companies [26].

Host country corruption, infrastructure level, and urbanization rate significantly negatively impact investment. However, some scholars also questioned the "purpose" of China's overseas arable land investment. For example, Böhme [27] believed China has been a significant participant in the global "land grab" since the global food crisis and suggested that the Australian Government strengthen foreign investment review. Jin et al. [28] also found that some European countries covered by "the belt and road" are hostile to overseas investment by Chinese companies. However, by exploring the Chinese company's investment in the Brazilian soybean sector, Oliveira [29] found that Chinese investment promotes agricultural upstream and downstream cross-border mergers and acquisitions. The challenge to the country and food sovereignty ultimately comes from the global soybean production system and does not depend on the national characteristics of the investor. Margulis and Porter [29] believed that the governance of global land grab embodies the complexity of transnational governance, and transnational land governance heralds a new change in the governance practices of global affairs. According to List and Qui [30], intellectual property rights and environmental regulations are critical for overseas investment.

As "overseas arable land investment" continues to receive widespread attention, the disputes and value judgments of overseas arable land investment [31-33], the transnational agricultural movement [34,35], the driving force of overseas arable land investment [36-38], risks assessment of global land acquisition [39,40], financialization [41,42], and other aspects of research results have matured and made positive progress. At the same time, Africa, as the primary destination for an overseas arable land investment, has also been studied by many scholars. Cotula and Vermulen [43] found that commodity price fluctuations, economic growth in emerging economies, and biofuel demand have led to a surge in arable land investment in Africa and discussed the main characteristics of overseas arable land investment. From the perspective of private equity investment, Shepard Daniel [44] discussed the impact of private equity financing on overseas arable land investment by explaining the development status of private equity in the African land market. Bekele et al. [45] conducted a survey and analysis of 866 households in Ethiopia and concluded that $43.7 \%$ of farm households faced a reduction in herd size and $55.8 \%$ of land loss due to large-scale land investment. In contrast, Ayelazuno [46] analyzed the actual situation of Ghana's attraction of foreign direct investment. In this case, he recognized the significance of the overseas arable land investment for agricultural transformation and industrialization in Ghana.

On the other hand, while scholars have evaluated China's overseas arable land investment in recent years [3,47], the existing literature does not comprehensively evaluate the potentialities of evaluating the suitability of the location of the host country for arable land investment. Therefore, it is so difficult to guide the overseas investment layout. However, the research scope of evaluating investment potentialities is relatively robust as many BRI countries have less investment but have good investment conditions [48]. Interestingly, evaluating the investment potential of arable land investment from the perspective of the spatial pattern is relatively rare. In a study, Lu et al. [23] utilized the spatial distribution pattern and its optimization strategy to capture the existing Chinese land investment, but they do not consider the interconnection among the factors associated with overseas land investment.

Therefore, the study's main aim is to comprehensively evaluate the potential of arable land investment by utilizing the macro data of 119 countries in 2010 and 2016 before and after the BRI. The article uses the fuzzy C-means clustering and the entropy weight method to craft the findings. More specifically, we use the ESDA, nuclear density estimation and 
trend surface method to analyze the evolution of arable land investment potential and reveal the spatial distribution pattern. The study's findings will be crucial to the scientific basis and decision-making support not only for Chinese enterprises but also can assist in global aspects to optimize overseas investment layout and reduce investment risks.

The following sections of the study lay the empirical setup of the study where the sample collection, methodology, and associated theories have been portrayed.

\section{Materials and Methods}

\subsection{Study Area and Data Source}

This article selects 119 countries along the BRI as the research objects, including 39 African countries, 35 Asian countries, 26 European countries, 3 Oceanian countries, 8 South American countries, and 8 North American countries (Table 1 and Figure 1). We use the data from 2010 to 2016 before and after the "belt and road initiative" was proposed to analyze the investment potential of arable land in various countries and compare the potential status before and after the initiative and its spatial distribution characteristics.

Table 1. Distribution of countries along with the "belt and road initiative".

\begin{tabular}{|c|c|c|}
\hline Region & $\begin{array}{c}\text { Number of } \\
\text { Countries (Number) }\end{array}$ & Country Name \\
\hline Africa & $39(1 \sim 39)$ & $\begin{array}{c}\text { South Africa, Senegal, Sierra Leone, Côted'Ivoire, Cameroon, Guinea, Ghana, Zambia, Mozambique, } \\
\text { Gabon, Namibia, Mauritania, Angola, Djibouti, Ethiopia, Kenya, Nigeria, Chad, Congo-Brazzaville, } \\
\text { Zimbabwe, Algeria, Tanzania, Burundi, Cape Verde, Uganda, Gambia, Togo, Rwanda, Morocco, } \\
\text { Madagascar Tunisia, Libya, Egypt, Liberia, Lesotho, Comoros, Benin, Mali, Niger }\end{array}$ \\
\hline Asia & $35(40 \sim 74)$ & $\begin{array}{c}\text { Korea, Mongolia, Timor-Leste, Malaysia, Myanmar, Cambodia, Vietnam, Laos, Brunei, Pakistan, Sri } \\
\text { Lanka, Bangladesh, Nepal, Maldives, UAE, Kuwait, Turkey, Qatar, Oman, Lebanon, Saudi Arabia, Iran, } \\
\text { Iraq, Afghanistan, Azerbaijan, Georgia, Armenia, Kazakhstan, Kyrgyzstan, Tajikistan Uzbekistan, } \\
\text { Thailand, Indonesia, Philippines, Yemen }\end{array}$ \\
\hline Europe & $26(75 \sim 100)$ & $\begin{array}{c}\text { Cyprus, Russia, Austria, Greece, Poland, Serbia, Czech Republic, Bulgaria, Slovakia, Albania, Croatia, } \\
\text { Montenegro, Estonia, Lithuania, Slovenia, Hungary, North Macedonia (formerly Macedonia), Romania, } \\
\text { Latvia, Ukraine, Belarus, Moldova, Malta, Portugal, Italy, Luxembourg }\end{array}$ \\
\hline Oceania & $3(101 \sim 103)$ & New Zealand, Papua New Guinea, Fiji \\
\hline South America & $8(104 \sim 111)$ & Chile, Guyana, Bolivia, Uruguay, Venezuela, Suriname, Ecuador, Peru \\
\hline North America & $8(112 \sim 119)$ & Costa Rica, Panama, El Salvador, Dominica, Trinidad and Tobago, Barbados, Cuba, Jamaica \\
\hline
\end{tabular}

Note: According to the "Guidelines for Foreign Direct Investment and Cooperation" issued by the Ministry of Commerce of China, Thailand, Bahrain, Uzbekistan, and Turkmenistan, they explicitly prohibit foreign investment in the field of agricultural investment. The study has not ignored the data of these countries to ensure the completeness of the research.

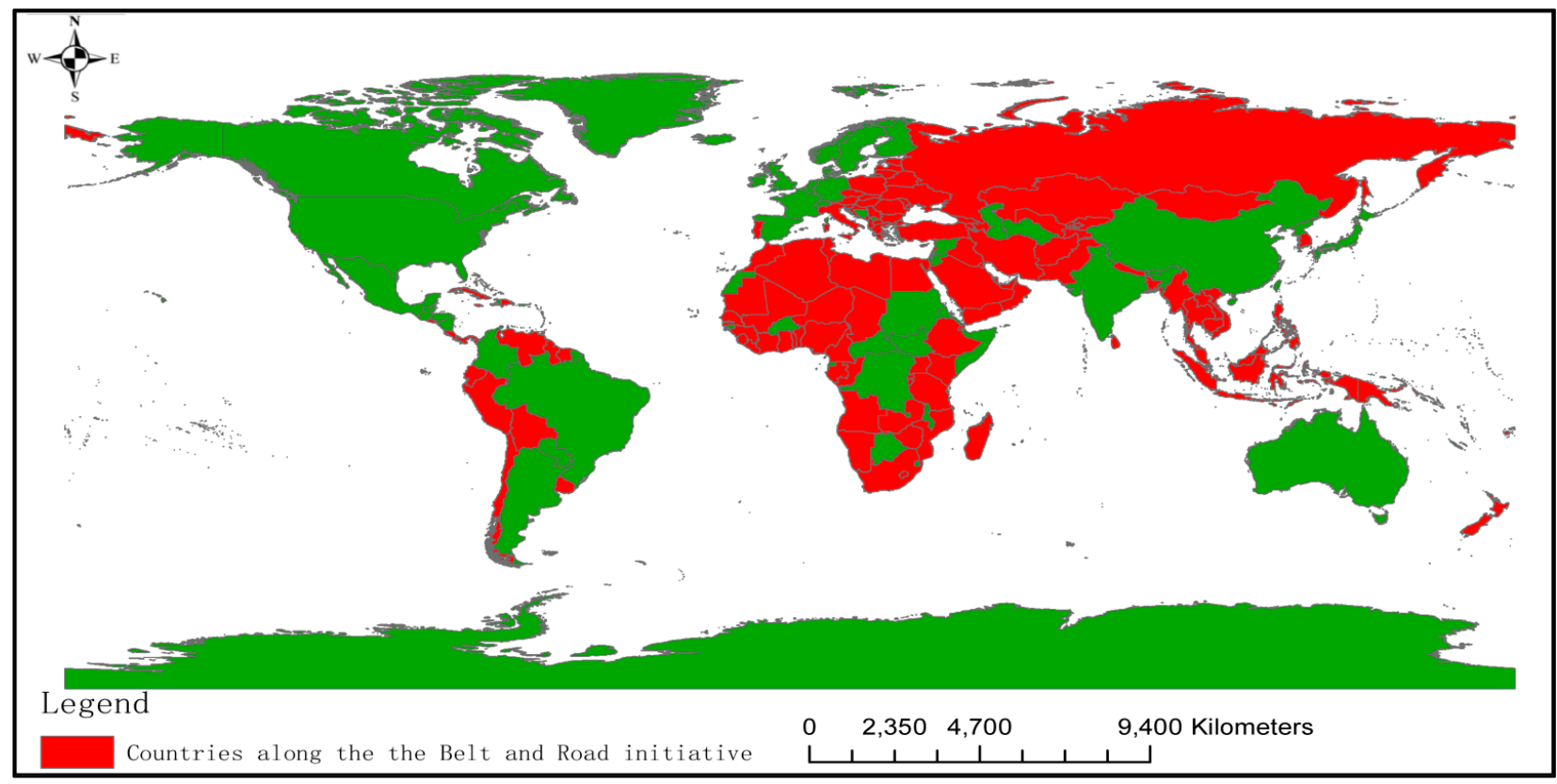

Figure 1. Graphical distribution of countries along with the "belt and road initiative". 
The data are mainly extracted from the World Bank statistics (http:/ / www.worldbank. org, accessed on 21 August 2021), Food and Agriculture Organization of the United Nations (http:/ / faostat.fao.org, accessed on 23 August 2021), International Trade Center (ITC) (https:/ / www.intracen.org/itc/sectors/services/tradestatistics, accessed on 25 August 2021), United States Department of Agriculture World (USDA) and other international databases.

\subsection{Methods}

\subsubsection{Fuzzy C-Means Clustering}

Clustering is a statistical anomaly detection approach that separates the population into multiple categories or clusters with datasets from the same grouping, representing identical, and data points from other groupings, representing distinct [49]. Fuzzy Cmeans clustering (FCM) is a clustering algorithm that uses the degree of membership to determine how each data point belongs to a specific cluster [50,51]. The geosciences research commonly uses FCM to evaluate the interconnection among specific clusters as a soft clustering system [52]. Bezdek [53] proposed the algorithm to improve the earlier Hard C Mean Clustering (HCM) method. The FCM is superior to other clustering methods such as K-means, as it comprehends the position by evaluating each data point among multiple clusters and its probability score or likelihood [54,55]. It is classified according to the membership degree of each category of the research object, and the classification is more accurate [56,57]. The principle of this method is to divide multiple vectors $\mathrm{X}_{i}(i=1,2, \ldots, \mathrm{n})$ into $C$ fuzzy groups and find the cluster center of each group so that the value function of the dissimilarity index is minimized [58]. Using this method to cluster the investment potential of arable land in the countries within BRI will help to grasp the characteristics of the overall potential of each country and provide a reference for enterprises to choose investment targets. The full workflow of the study has been portrayed in Figure 2. The specific equations are as follows:

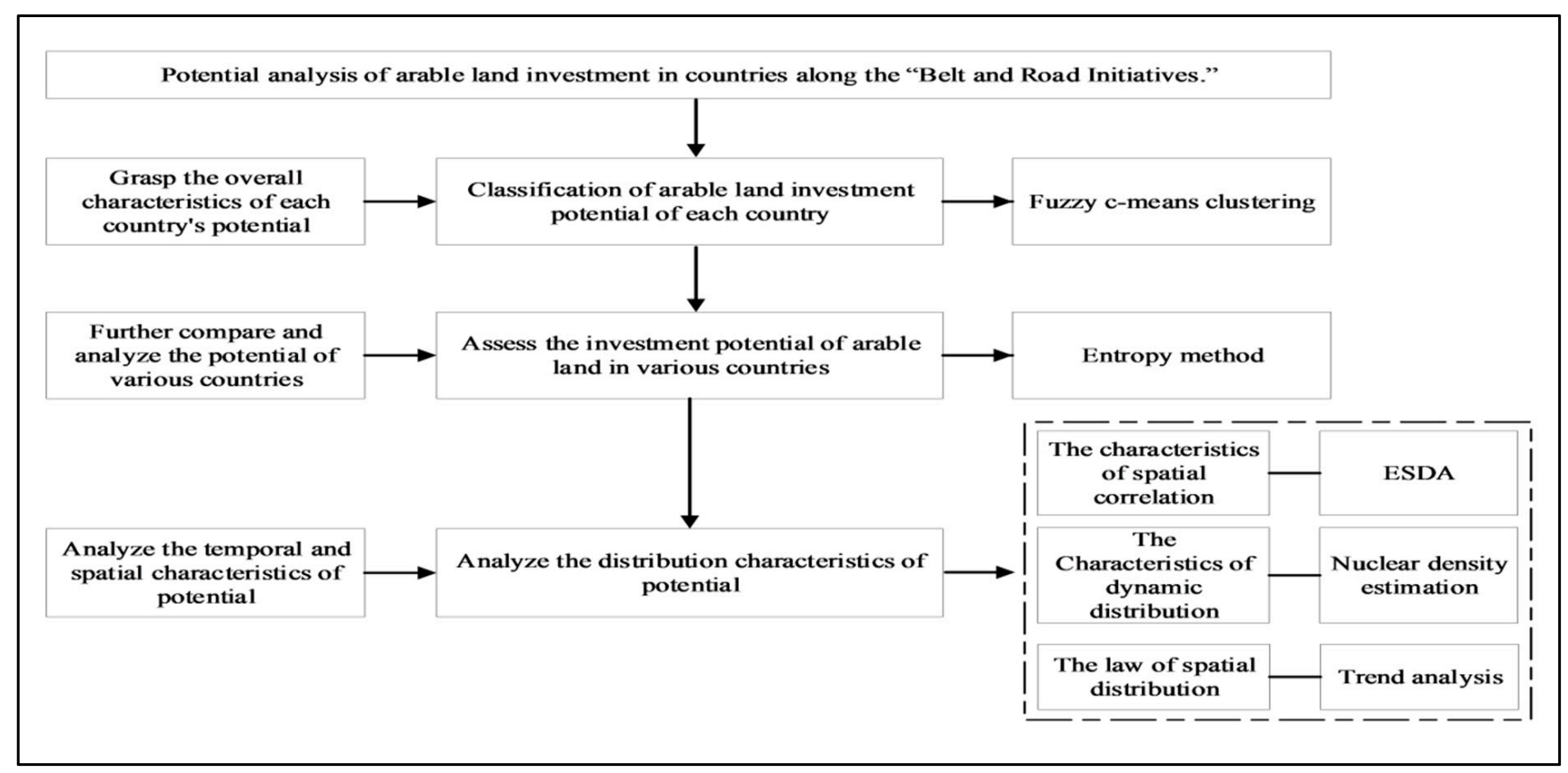

Figure 2. Workflow of the study.

Let $U=\left\{X_{1}, X_{2}, \ldots, X_{n}\right\}$ as the sample set of $n$ attributes, $c$ is the given number of classifications, $\mathrm{mi}(i=1,2, \ldots, \mathrm{c})$ is the center of each cluster, and $\mu(\mathrm{i})$ is the affiliation 
function of the $i$ th sample for the $j$ th class. The objective function of fuzzy C-means clustering $(\mathrm{FCM})$ is:

$$
J_{i}=\sum_{i=1}^{c} \sum_{j=1}^{n}[\mu(\mathrm{i})] b d_{i j^{2}}
$$

where $\mathrm{d}_{i j}=x_{i}-m_{j}^{2}$; is a constant that can control the clustering results. Under the condition of $\sum_{j=1}^{c} \mu_{j}\left(x_{i}\right)=1$, the Lagrange multiplier method (for more details, please cheek Bertsekas [59]) is used to find the minimal value of the objective function based on the following equations:

$$
\begin{gathered}
m_{i}=\frac{\sum_{i=1}^{n}\left[\mu_{i}(i)\right]^{h} x_{j}}{\sum_{i=1}^{n}\left[\mu_{j}(i)\right]^{b}}(j=1,2,3, \ldots, n) \\
\mu_{j}\left(\mathrm{x}_{\mathrm{i}}\right)=\frac{\left(\frac{1}{d_{i j}}\right)^{\frac{1}{h-1}}}{\sum_{k=1}^{c}\left(\frac{1}{d_{i j}}\right)^{\frac{1}{b-1}}}(i=1,2, \ldots, n ; j=1,2, \ldots, \mathrm{c})
\end{gathered}
$$

\subsubsection{Entropy Method}

In the article, the entropy weighting method (EWM) is chosen to assign weights to each indicator and calculate the value of arable land investment potential for each country, as suggested by Ahn [60]. EWM is a frequently used weighting method that measures value dispersion in decision-making [61]. The calculation steps are as follows:

(i) The standardization process has been performed as suggested by [62]. In order to eliminate the magnitude of each variable, the indicators need to be standardized to make them comparable with each other. The specific calculation formula is as follows:

$$
Y_{i j}=\frac{x_{i j}-\min \left(x_{1 j}, \cdots, x_{n j}\right)}{\max \left(x_{1 j}, \cdots, x_{n j}\right)-\min \left(x_{1 j}, \cdots, x_{n j}\right)}
$$

The equation is applied to positive indicators.

$$
Y_{i j}=\frac{\max \left(x_{1 j}, \cdots, x_{n j}\right)-x_{i j}}{\max \left(x_{1 j}, \cdots, x_{n j}\right)-\min \left(x_{1 j}, \cdots, x_{n j}\right)}
$$

The equation is applied to negative indicators.

(ii) Determine the entropy value of each indicator. We calculate the weight of the $i$ th sample value under the $j$ th indicator by using the following equation:

$$
p_{i j}=\frac{Y_{i j}}{\sum_{i=1}^{n} Y_{i j}}, i=1, \cdots, n ; j=1, \cdots, m
$$

The entropy value of the $j$ th indicator is then calculated as follows:

$$
e_{j}=-k\left(\sum_{i=1}^{n} p_{i j} \times \ln p_{i j}\right), i=1, \cdots, n ; j=1, \cdots, m ; e_{j} \geq 0, k=\frac{1}{\ln n}>0
$$

If $p_{i j}=0$, then the definition would be $\lim _{p_{i j \rightarrow 0}} \ln p_{i j}=0$

(iii) Determine the weights of each indicator. The weight $w_{-} j$ of the $j$ th indicator is:

$$
w_{j}=\frac{\gamma_{j}}{\sum_{j=1}^{m} \gamma_{j}}, j=1, \cdots, m
$$


where $\gamma_{j}=1-e_{j}, j=1, \cdots, m$, denotes the information entropy redundancy.

(iv) The weights of the indicators are weighted to obtain the composite index of the ith object.

$$
z_{i}=\sum_{i=1}^{n} w_{j} \times Y_{i j}, i=1, \cdots, n ; j=1, \cdots, m
$$

\subsubsection{Exploratory Spatial Data Analysis Methods (ESDA)}

Exploratory spatial data analysis methods mainly describe the spatial clustering and correlation of geographical things, including global spatial autocorrelation and local spatial autocorrelation [63]. Global spatial autocorrelation examines the correlation and difference of variables in the overall regional space. It can determine whether spatial variables take values related to adjacent spaces and study the overall trend of spatial correlation of variables in the region. The commonly used characterization indices are "Moran's I and Geary's C." In the study, the "Moran's I" index is used to measure the global spatial autocorrelation of arable land investment potential in the countries along BRI, as suggested by De Jong et al. [58]. The formula is as follows:

$$
\text { Global }- \text { Moran' }^{\prime} I=\frac{n \sum_{i=1}^{n} \sum_{j=1}^{n} w_{i j}\left(x_{i}-\bar{x}\right)\left(x_{j}-\bar{x}\right)}{\sum_{i=1}^{n} \sum_{j=1}^{n} w_{i j} \times \sum_{i=1}^{n}\left(x_{i}-\bar{x}\right)^{2}}
$$

where $n$ is the number of countries studied, $x_{i}$ and $x_{j}$ denote the investment potential of arable land in countries $i$ and $j$, respectively. $\bar{x}=\sum_{i=1}^{n} x_{i}, w_{i j}$ is the spatial weight matrix. Moran's I range between -1 and 1 , and an immense value indicates a more significant regional correlation. Moran's I $>0$ indicates that the investment potential of arable land in countries along with the BRI is positively correlated spatially, and the larger values are aggregate to similar attribute values. Conversely, Moran's $I<0$ indicates that the investment potential is negatively correlated spatially, and a smaller the value indicates that the aggregation of dissimilar attribute values becomes more pronounced, while Moran's $I=0$ indicates that there is no spatial correlation in the investment potential.

Local autocorrelation examines the correlation and variability of variables in the local space of a region (for more details about local autocorrelation, please cheek De Jong et al. [64] and Papalia and Bertarelli [65]). Global autocorrelation cannot determine the specific spatial clustering characteristics and their significance within the study area, while local spatial autocorrelation can measure the local spatial correlation between each area and its surrounding areas [66]. The calculation formula is as follows:

$$
\text { Local-Moran's } I=\frac{n^{2}\left(x_{i}-\bar{x}\right) \sum_{j=1}^{n} w_{i j}\left(x_{j}-\bar{x}\right)}{\sum_{i=1}^{n} \sum_{j=1}^{n} w_{i j} \times \sum_{j=1}^{n}\left(x_{j}-\bar{x}\right)^{2}}
$$

Local-Moran's I $>0$ indicates that the country has similar properties to neighboring countries. Local-Moran's $I<0$ indicates that the country is not similar to its neighboring countries in terms of attributes.

The above analysis method constructs the weight matrix by whether the two countries are adjacent to each other, which only considers the possible spatial interaction between adjacent areas. However, practice proves that there is still a strong interaction between two geographically close countries but not adjacent to each other. The geographic distance matrix can better compensate for this deficiency [67]. Therefore, the study constructs a geographic distance matrix, which is expressed as the inverse of the surface distance between two countries:

$$
\mathrm{W}_{\mathrm{ij}}=\left\{\begin{array}{r}
\frac{1}{d_{i j}}, i \neq j \\
0, i=j
\end{array}\right.
$$


where $d_{i j}$ denotes the geographical distance between the two countries, the distance between the two places is calculated based on the longitude and dimension of each country's capital location. The closer the two places are, the higher the weight is, and vice versa if the weight is relatively lower.

Spatial linkages reflected by geographic location differences can only characterize the influence of geographic proximity features, which are relatively coarse. The spatial characteristics of arable land investment potential are inevitably influenced by various nongeographic factors in combination [68], requiring the spatial weight matrix to be refined from different perspectives. The economic conditions of different countries are spatially correlated, and the intensity of the interaction between the two countries is not necessarily the same [69]. Therefore, in the article, a new spatial matrix of economic distances is established by combining the geographic distance matrix and the economic situation of each country. The specific formula is:

$$
\mathrm{W}=\mathrm{W}_{\mathrm{ij}} \operatorname{diag}\left(\overline{Y_{1}} / \bar{Y}, \overline{Y_{2}} / \bar{Y}, \ldots, \overline{Y_{n}} / \bar{Y}\right)
$$

where $\overline{Y_{t}}=\frac{1}{t_{1}-t_{0}+1} \sum_{t=t_{0}}^{t_{1}} Y_{i t}$ is the average of the gross domestic product (GDP) of country $\mathrm{i}$ in the period under examination. $\bar{Y}=\frac{1}{n\left(t_{1}-t_{0}+1\right)} \sum_{i=1}^{n} \sum_{t=t_{0}}^{t_{1}} Y_{i t}$ is the average of total GDP of each country in the period under examination. The above matrix shows that when a country has a larger share of total GDP, its impact on neighboring countries is also significant.

\subsubsection{Nuclear Density Estimation}

Kernel density estimation is used in probability theory to estimate the density function of the location, and it belongs to one of the nonparametric testing methods, as recommended by Botev et al. [70]. The article uses the kernel density estimation method to analyze the dynamic distribution characteristics of arable land investment potential in countries along the BRI. Suppose the density function of the random variable $X$ is $f(x)$. The estimated probability density of point $\mathrm{x}$ is given by:

$$
f_{x}=\frac{1}{N h} \sum_{i=1}^{N} K\left(\frac{X_{i}-x}{h}\right)
$$

where $N$ denotes the number of observations, $h$ is the bandwidth $X_{i}$ is the observation, and $x$ is the mean value. $K(\cdot)$ is the kernel function, and the Gaussian function is chosen for estimation in this analysis, and the expressions are:

$$
\begin{gathered}
\mathrm{K}(\mathrm{x})=\frac{1}{\sqrt{2 \pi}} \exp \left(-\frac{x^{2}}{2}\right) \\
\lim _{N \rightarrow \infty} h(N)=0, \lim _{N \rightarrow \infty} N h(N)=N \rightarrow \infty
\end{gathered}
$$

\subsubsection{Trend Analysis}

The trend surface approximates the actual surface and accurately simulates the distribution pattern of geographic elements in space [71]. The study explores the divergent trends in the countries' spatial patterns of arable land inves tment potential along BRI by employing trend surface. Assuming that $Z_{i}\left(x_{i}, y_{i}\right)$ is the arable land investment potential of a country and $\left(x_{i}, y_{i}\right)$ is the spatial plane coordinates, the calculation formula is:

$$
Z_{i}\left(x_{i}, y_{i}\right)=T_{i}\left(x_{i}, y_{i}\right)+\varepsilon_{i}
$$

where $T_{i}\left(x_{i}, y_{i}\right)$ is a trend function indicating the trend of investment in arable land in each country, while $\varepsilon_{i}$ is the auto-correlated random error, reflecting the error between each country's actual and trend values of arable land investment potential. In the analysis, 
a second-order polynomial is used to measure the trend value, as it is superior to other methods such as data-scape and kriging [72], and the formula is:

$$
T_{i}\left(x_{i}, y_{i}\right)=\beta_{0}+\beta_{1} x+\beta_{2} y+\beta_{3} x^{2}+\beta_{4} y^{2}+\beta_{5} x y
$$

\subsection{Indicator System Construction}

The article draws on the index system constructed by Tian et al. [26], with the arable land investment potential evaluation index system as the target layer and the resource endowment, production conditions, economic conditions, and political environment of the host country as the criterion layer (Table 2). As each region has not quantified the same land prices, and, the deal is confidential most of the time, access to the transaction amount of relevant data is relatively rare $[73,74]$, and therefore, for constructing the index, the study omits the price of land.

Table 2. Evaluating the index system of arable land investment potential.

\begin{tabular}{cccc}
\hline Target Layer & Guideline Layer & Indicator Layer & Unit \\
\hline & & Arable land per capita & ha/per \\
ha \\
& Resource Endowment & Arable land area & Land area \\
& & Agricultural land area & ha \\
& & The proportion of arable land that can be expanded & $\%$ \\
& & Annual freshwater withdrawal for agriculture & cubic meter \\
& Production conditions & Crop production index & - \\
& Food production index & - \\
Arable land investment & & Total workforce & per \\
potential evaluation & & Percentage of employed persons in agriculture & $\%$ \\
index system & & Cereal production & $\mathrm{kg} / \mathrm{ha}$ \\
& Economic conditions & GDP per capita & USD \\
& & GDP growth rate & $\%$ \\
& & Logistics performance index & - \\
& & Civil rights & - \\
& & Political and social stability & - \\
& Political Environment & Government efficiency & - \\
& & Quality of social regulation & - \\
& Laws and regulations & - \\
\hline
\end{tabular}

\subsubsection{Resource Endowment}

Resource endowment is an investment background resource composed of natural geographic conditions, determining regional arable land investment [75]. It is generally difficult to change in the short term, including arable land and agricultural land. In the study, the resource endowment is expressed by five indicators: arable land area per capita, arable land area, national land area, agricultural land area, and arable land expandable ratio. Among them, the arable land expandable ratio refers to the difference between the ratio of agricultural land to the national land area of the country and the ratio of arable land area to the national land area. If a country possessed a rich resource endowment, there would be more significant investment potential [76].

\subsubsection{Production Conditions}

Production conditions include material conditions, production materials, and labor conditions, including agricultural water, quality of arable land, and labor conditions, in addition to the existing arable land area. The better production conditions provide a significant potential for investment in arable land in the country [77]. In the analysis, five indicators indicate the production conditions: annual freshwater withdrawal from 
agriculture, crop production index, food production index, total labor force, and the share of employed people in agriculture.

\subsubsection{Economic Conditions}

In addition to land and labor, capital is also a key factor of production, and the economic conditions reflect the labor cost of the country, which is the primary consideration for the export of capital from the investing country to the host country [78]. Apart from per capita GDP and GDP growth rate, the analysis adds cereal production and logistics performance indices to characterize the national economy. While cereal production reflects the country's agricultural productivity to a certain extent, the logistics performance index reflects the level of logistics and trade.

\subsubsection{Political Environment}

Political environment refers to a country's general political context in a certain period concerning the country's dealings with other countries and cooperation. A country with a good political environment and resources can attract more countries to cooperate and invest [79]. On the contrary, even if a country has rich resources, if the political environment is unstable, policy changes frequently, and there is a high level of corruption, it is difficult to attract investment from other countries [80]. Therefore, the political environment can have a significant impact on the investment potential of arable land. The article characterizes the political environment of each country using six indicators: civil rights, political and social stability, government efficiency, quality of social regulation, laws and regulations, and control of corruption.

\section{Results}

\subsection{Evaluation of the Investment Potential of the Host Country's Arable Land}

Arable land investment potential is a relatively fuzzy concept [81]. The study classifies each country's arable land investment potential into the corresponding categories more accurately by fuzzy C-mean clustering to analyze the distribution of investment potential of each country in a preliminary comparison. The countries are classified into three categories according to their arable land investment potential characteristics. Namely, high investment potential, average potential, and low potential, and the relevant data are clustered for 2010 and 2016, respectively. The results show that the classification of arable land investment potential in countries along the BRI has not changed much between 2010 and 2016, and only a few countries have changed their potential categories. Among the 119 countries in 2016, 50 countries have a high potential for investment in arable land, two more than in 2010,39 countries are of average potential for investment in arable land, two more than in 2010, and 30 countries have a low potential for investment in arable land, four less than in 2010.

Overall, $42 \%$ of the countries have a high potential for an arable land investment, and only $25 \%$ of the countries have a low potential for an arable land investment, indicating that the countries along the BRI have a better investment environment and can be China's first choice for arable land investment. In addition, the clustering results show that $90 \%$ of the countries with high arable land investment potential in 2016 are located in Africa and Asia, with most European countries having average arable land investment potential. However, most countries with low potential are still concentrated in Africa and Asia, indicating that African and Asian countries along the BRI have more potential for arable land investment than other regions (Table 3). 
Table 3. Distribution of arable land investment potential in countries with the "belt and road initiative" in 2010 and 2016.

\begin{tabular}{cccccccc}
\hline & \multicolumn{7}{c}{ Region and Period } \\
\cline { 2 - 8 } Category & Africa & Asia & Europe & Oceania & South America & North America & Total \\
\cline { 2 - 8 } & $\mathbf{2 0 1 0 / 2 0 1 6}$ & $\mathbf{2 0 1 0 / 2 0 1 6}$ & $\mathbf{2 0 1 0 / 2 0 1 6}$ & $\mathbf{2 0 1 0 / 2 0 1 6}$ & $\mathbf{2 0 1 0 / 2 0 1 6}$ & $\mathbf{2 0 1 0 / 2 0 1 6}$ & $\mathbf{2 0 1 0 / 2 0 1 6}$ \\
\hline High potential & $27 / 27$ & $16 / 18$ & $1 / 2$ & $1 / 1$ & $3 / 2$ & $0 / 0$ & $48 / 50$ \\
Average & $2 / 3$ & $7 / 8$ & $20 / 20$ & $1 / 1$ & $2 / 2$ & $5 / 5$ & $37 / 39$ \\
potential & $10 / 9$ & $12 / 9$ & $5 / 4$ & $1 / 1$ & $3 / 4$ & $3 / 3$ & $34 / 30$ \\
Low potential & & & & & & & \\
\hline
\end{tabular}

\subsection{Analysis of the Investment Environment in Different Dimensions}

In order to assess the investment environment of the countries along the BRI, the study analyzes the four dimensions (resource endowment, production conditions, economic conditions, and political environment) through fuzzy C-mean clustering. In addition to the vast investment potential of each country, we explore the distribution of resources in each dimension to provide more detailed reference information for the investment countries. The study is intended to provide more detailed reference information for investing countries.

The distribution of countries' resource endowments along the BRI in 2016 is not very different from that in 2010, but in general, there is a slight trend of positive changes in the investment potential of arable land (Figure 3). In terms of resource endowment, most countries with high potential for investment in arable land are mainly located in Africa and Asia, while some countries with low potential still exist in Africa and Asia. While most European countries have poor resource endowment status and low investment potential, countries in other continents have the average potential for investment in arable land. Overall, results show that African and Asian countries have a more significant advantage in resource endowment and have more significant potential for development.

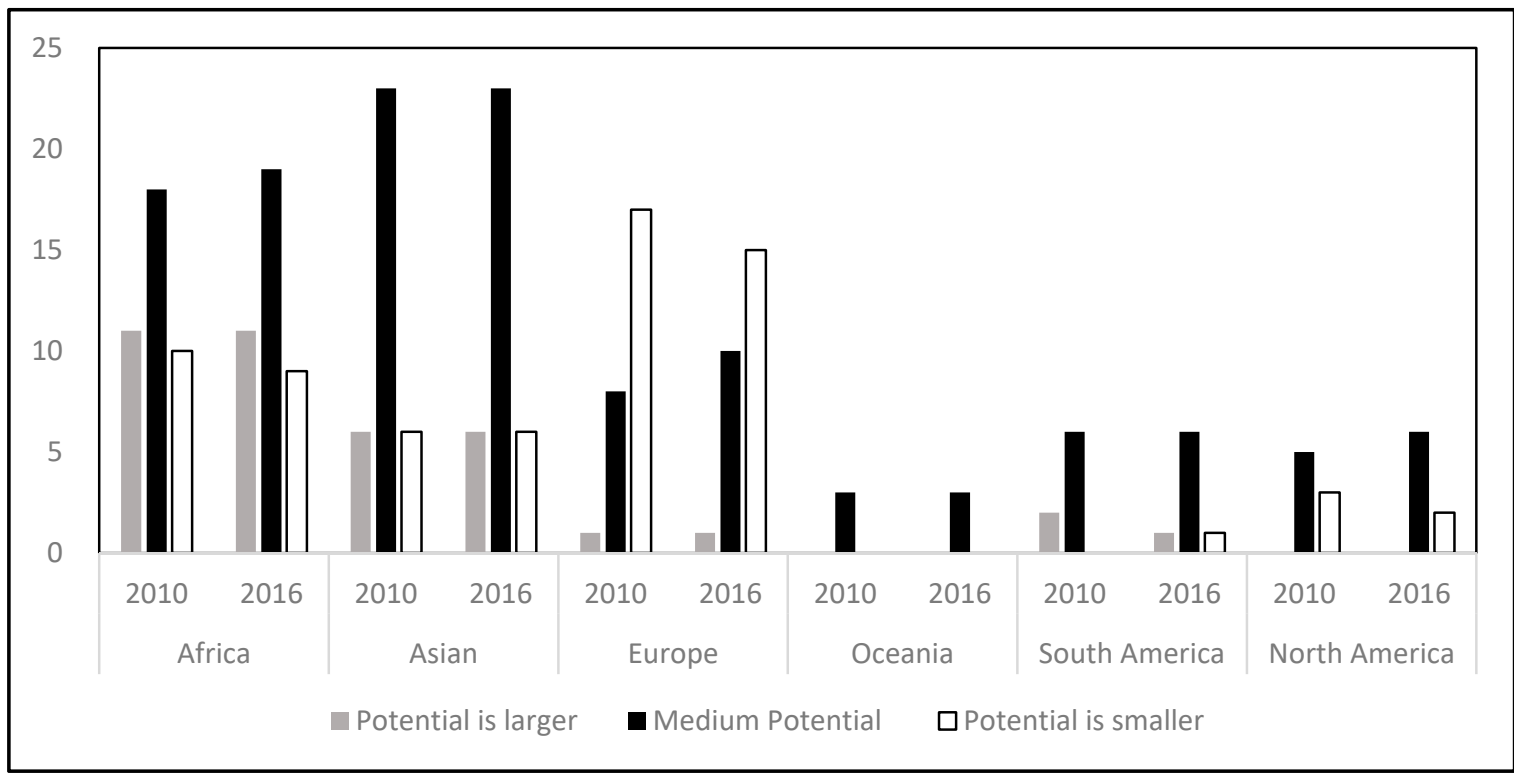

Figure 3. Distribution of resource endowments within "the belt and road initiative" countries.

As shown in Figure 4, in 2016 and 2010, the distribution pattern of production conditions in countries along the BRI has changed relatively little, and the countries with more significant investment potential are still mainly concentrated in Africa and Asia. Most European countries have less investment potential. This could be due to the fact that most developing countries in Africa and Asia are predominantly agricultural countries with better production conditions regarding the amount of fresh water in agriculture and people employed in agriculture [82]. European countries have less productive conditions, 
probably due to the gradual shift of gravity to non-agriculture in most European countries, with fewer resources remaining for agricultural production.

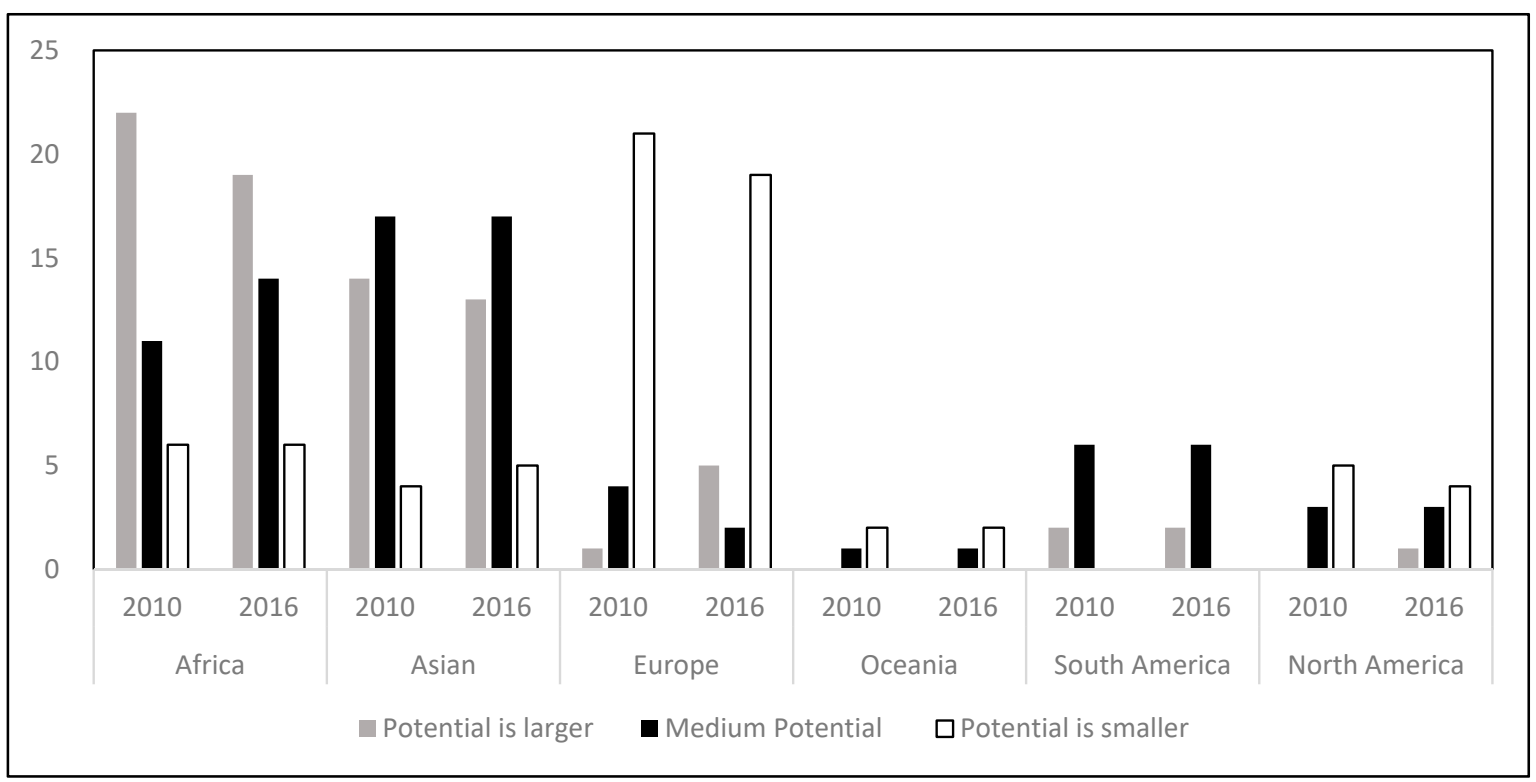

Figure 4. Distribution of production conditions within "the belt and road initiative" countries.

Figure 5 shows that the economic conditions of the countries along the BRI in 2016 are significantly higher than those in 2010. The economic conditions of some African and Asian countries are unstable and found low to average investment potential, and some European countries have average to high investment potential. There was little change in Oceania. Additionally, America shifted from average to higher investment potential. However, as most African and Asian countries still have economic barriers, they have small investment potential, indicating that the economic conditions are still the shortcomings of investment in arable land in Africa and Asia. In contrast, European countries have a more significant advantage in economic conditions.

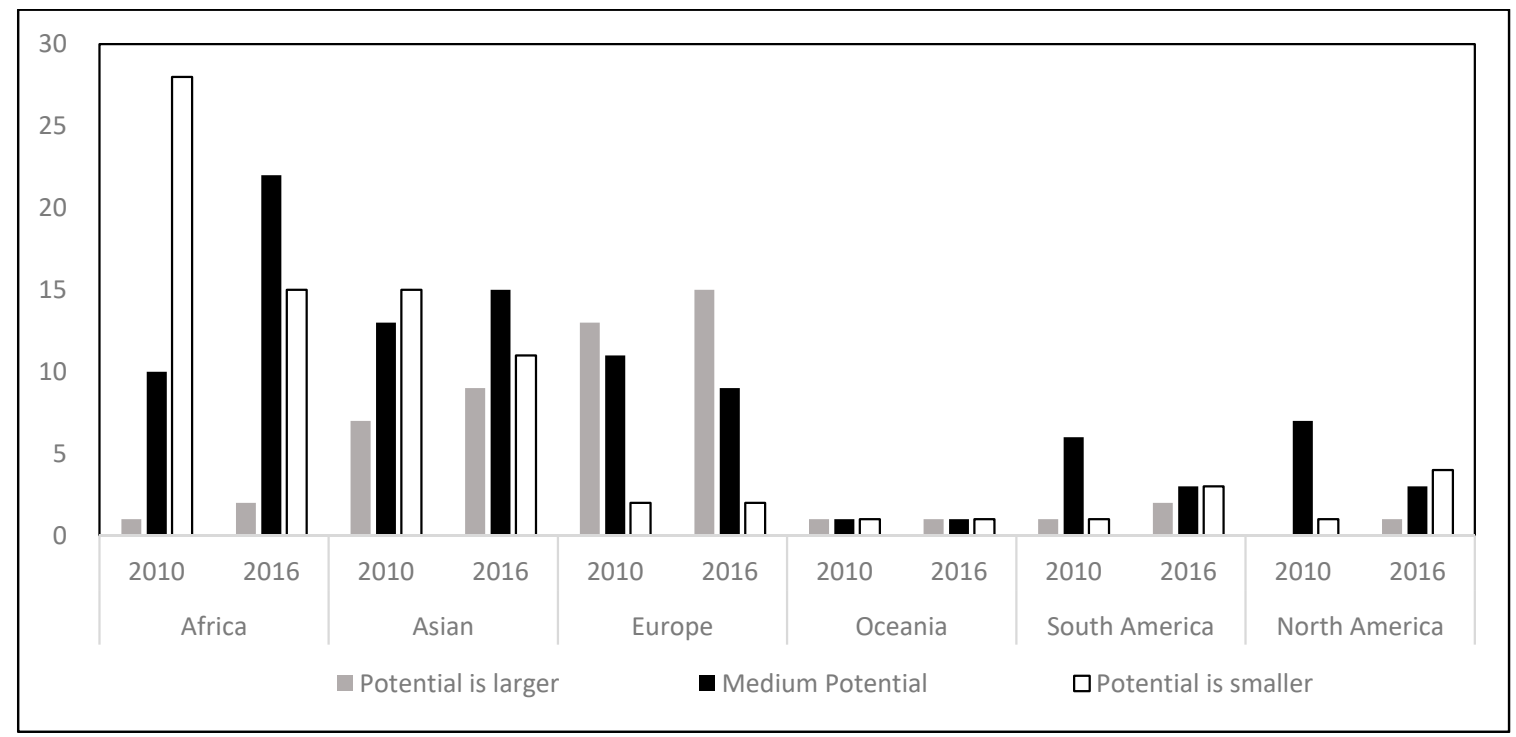

Figure 5. Distribution of economic conditions within "the belt and road initiative" countries.

As shown in Figure 6, the deterioration of the political environment in African countries between 2010 and 2016 has led to low potential for investment in arable land in most 
countries. Asia also has a more significant portion of countries with less potential for investment in the political environment and still has more room for improvement. The political environment in European countries has always remained relatively good, with most countries having average and above arable land investment potential.

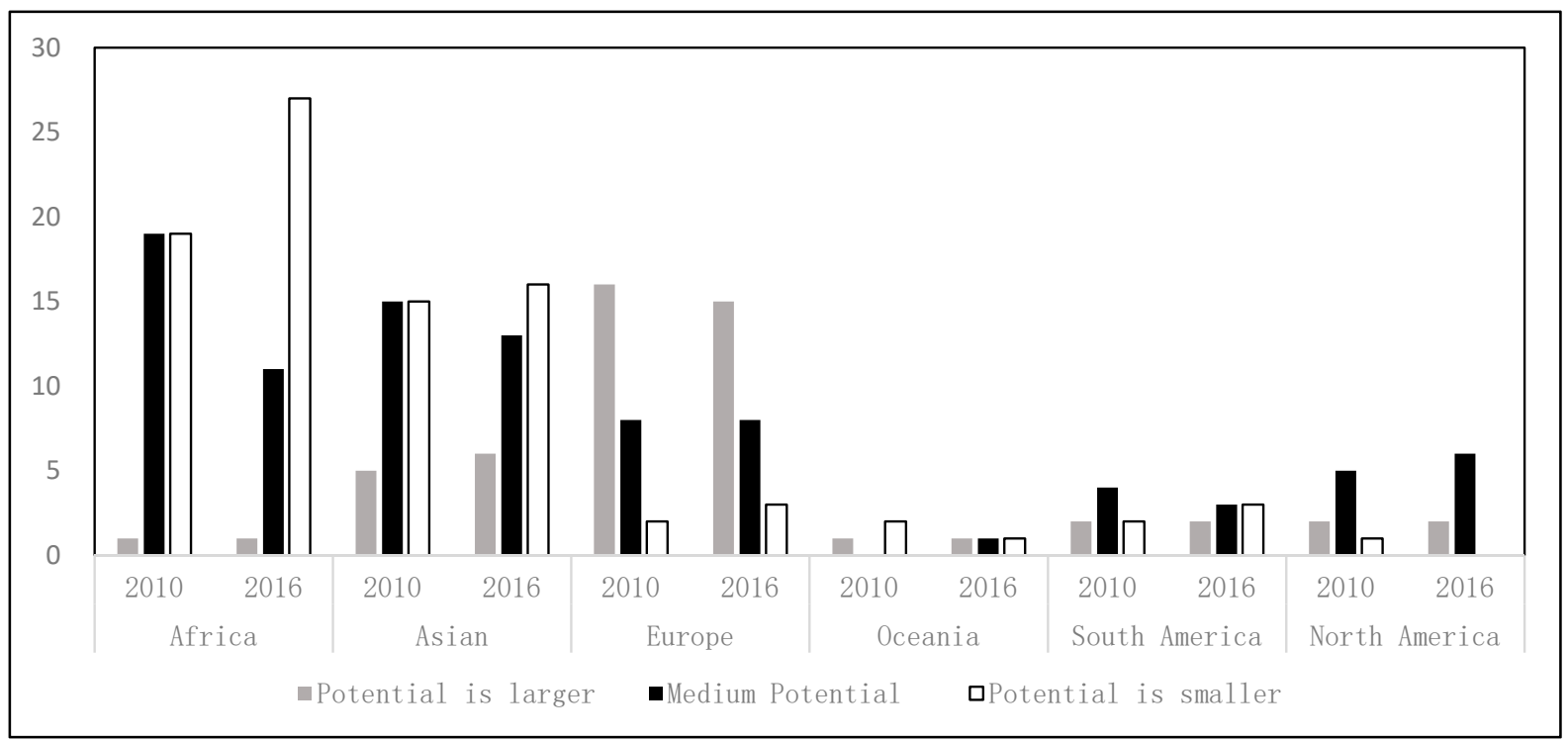

Figure 6. Distribution of political environment within "the belt and road initiative" countries.

\subsection{Investment Potential Value of Arable Land}

The fuzzy C-mean clustering method provides a comprehensive cluster of 119 countries' arable land investment potential by size but cannot derive the specific potential value of each country and its ranking [83]. Therefore, the study uses the entropy weighting method to analyze further and assign weights to each indicator to calculate the potential value and provide relevant data for studying the spatial correlation of arable land investment potential, as suggested by Lu and Huang [84]. By calculating each indicator of arable land investment potential (Table 4), it can be seen that there is not much difference between the weight values derived using 2010 and 2016 data.

Table 4. Weight of each index of arable land investment potential within "the belt and road initiative countries".

\begin{tabular}{|c|c|c|c|c|c|}
\hline Guideline Layer & 2010 Weights & 2016 Weights & Indicator Layer & 2010 Weights & 2016 Weights \\
\hline \multirow{5}{*}{$\begin{array}{c}\text { Resource } \\
\text { Endowment }\end{array}$} & \multirow{5}{*}{0.5080} & \multirow{5}{*}{0.5176} & Arable land per capita & 0.0519 & 0.0575 \\
\hline & & & Arable land area & 0.1506 & 0.1529 \\
\hline & & & Land area & 0.1634 & 0.1642 \\
\hline & & & Agricultural land area & 0.1317 & 0.1327 \\
\hline & & & The proportion of arable land that can be expanded & 0.0103 & 0.0104 \\
\hline \multirow{5}{*}{$\begin{array}{l}\text { Production } \\
\text { conditions }\end{array}$} & \multirow{5}{*}{0.2173} & \multirow{5}{*}{0.2243} & Annual freshwater withdrawal for agriculture & 0.0290 & 0.0283 \\
\hline & & & Crop production index & 0.0161 & 0.0164 \\
\hline & & & Food production Index & 0.0106 & 0.0157 \\
\hline & & & Total workforce & 0.1181 & 0.1163 \\
\hline & & & Percentage of employed persons in agriculture & 0.0435 & 0.0477 \\
\hline \multirow{4}{*}{$\begin{array}{l}\text { Economic } \\
\text { conditions }\end{array}$} & \multirow{4}{*}{0.1652} & \multirow{4}{*}{0.1636} & Cereal production & 0.0351 & 0.0415 \\
\hline & & & GDP per capita & 0.1087 & 0.1016 \\
\hline & & & GDP growth rate & 0.0102 & 0.0040 \\
\hline & & & Logistics performance index & 0.0111 & 0.0165 \\
\hline \multirow{6}{*}{$\begin{array}{c}\text { Political } \\
\text { Environment }\end{array}$} & \multirow{6}{*}{0.1095} & \multirow{6}{*}{0.0946} & Civil rights & 0.0185 & 0.0207 \\
\hline & & & Political and social stability & 0.0123 & 0.0107 \\
\hline & & & Government efficiency & 0.0208 & 0.0165 \\
\hline & & & Quality of social regulation & 0.0123 & 0.0138 \\
\hline & & & Laws and regulations & 0.0210 & 0.0113 \\
\hline & & & Control of corruption & 0.0246 & 0.0216 \\
\hline
\end{tabular}


However, the study mainly relies on the 2016 results for the interpretation of its outcomes. Resource endowment in the criterion layer contributes the most to the investment potential of arable land, with a weight of $51.76 \%$, and the country area plays the most significant role, with a weight of $16.42 \%$. The situation is followed by production conditions, which contribute $22.43 \%$ to the investment potential, with the most significant weight of $11.63 \%$ for the total labor force in the indicator layer. The economic conditions contribute $16.36 \%$, and the most significant weight is $10.16 \%$ for GDP per capita. Seemingly, the political environment contributes less to the investment potential of arable land, with a weight of $9.46 \%$.

The combined value of arable land investment potential for each country was calculated by evaluating the weights in Table 4 with the standardized indicator values, and the results are shown in Table 5. There is little change in the potential values between 2010 and 2016 for each country, and the 2016 results are used as the primary basis for the analysis. The five countries with the highest potential values are Russia, Kazakhstan, Indonesia, Saudi Arabia, and Pakistan. The five countries with the lower potential are Maldives, Lesotho, Congo (Brazzaville), Gambia, and Montenegro. A total of 10 Asian countries, 6 African countries, 3 European countries, and 1 Oceanian country are among the top 20 countries in investment potential value. The bottom 20 countries include 4 Asian countries, 8 African countries, 4 European countries, 3 North American countries, and 1 Oceanian country. As per the range of larger and smaller investment potentials, both Asian and African countries account for a larger share, while the investment potentials of countries in other continents are mainly in the middle stage, further verifying the cluster analysis's conclusion.

Table 5. The potential value of the arable land investment in countries along the "belt and road" initiative.

\begin{tabular}{|c|c|c|c|c|c|}
\hline Country & Potential Value (2010/2016) & Country & Potential Value (2010/2016) & Country & Potential Value (2010/2016) \\
\hline South Africa & $0.2437 / 0.2331$ & Mongolia & $0.2149 / 0.2196$ & Czech Republic & $0.1544 / 0.1475$ \\
\hline Senegal & $0.1534 / 0.1469$ & East Timor & $0.1232 / 0.1175$ & Bulgaria & $0.1315 / 0.1305$ \\
\hline Sierra Leone & $0.1199 / 0.1221$ & Malaysia & $0.1575 / 0.1485$ & Slovakia & $0.1374 / 0.1358$ \\
\hline Côted'Ivoire & $0.1194 / 0.1378$ & Myanmar & $0.1554 / 0.1724$ & Albania & $0.1348 / 0.1404$ \\
\hline Cameroon & $0.1478 / 0.1437$ & Cambodia & $0.1499 / 0.1483$ & Croatia & $0.1361 / 0.1312$ \\
\hline Guinea & $0.1256 / 0.1346$ & Vietnam & $0.2020 / 0.2008$ & Montenegro & $0.0975 / 0.0838$ \\
\hline Ghana & $0.1722 / 0.1592$ & Laos & $0.1447 / 0.1588$ & Estonia & $0.1546 / 0.1574$ \\
\hline Zambia & $0.1813 / 0.1699$ & Brunei & $0.1452 / 0.1223$ & Lithuania & $0.1507 / 0.1729$ \\
\hline Mozambique & $0.2059 / 0.1868$ & Pakistan & $0.2304 / 0.2439$ & Slovenia & $0.1510 / 0.1352$ \\
\hline Gabon & $0.1177 / 0.1046$ & Sri Lanka & $0.1391 / 0.1356$ & Hungary & $0.1426 / 0.1355$ \\
\hline Namibia & $0.1720 / 0.1647$ & Bangladesh & $0.1906 / 0.1873$ & North Macedonia & $0.1320 / 0.1122$ \\
\hline Mauritania & $0.1578 / 0.1544$ & Nepal & $0.1476 / 0.1513$ & Romania & $0.1531 / 0.1556$ \\
\hline Angola & $0.1667 / 0.1699$ & Maldives & $0.0841 / 0.0719$ & Latvia & $0.1454 / 0.1666$ \\
\hline Djibouti & $0.0962 / 0.0860$ & UAE & $0.2019 / 0.2059$ & Ukraine & $0.1987 / 0.2072$ \\
\hline Ethiopia & $0.2261 / 0.2289$ & Kuwait & $0.1763 / 0.1435$ & Belarus & $0.1235 / 0.1154$ \\
\hline Kenya & $0.1687 / 0.1795$ & Turkey & $0.2298 / 0.2135$ & Moldova & $0.1053 / 0.1085$ \\
\hline Nigeria & $0.2370 / 0.2354$ & Qatar & $0.2135 / 0.1724$ & Malta & $0.1615 / 0.1398$ \\
\hline Chad & $0.1846 / 0.1764$ & Oman & $0.1581 / 0.1556$ & Portugal & $0.1835 / 0.1691$ \\
\hline Congo (Brazzaville) & $0.0795 / 0.0790$ & Lebanon & $0.1030 / 0.0858$ & Italy & $0.2082 / 0.1901$ \\
\hline Zimbabwe & $0.1315 / 0.1323$ & Saudi Arabia & $0.2767 / 0.2688$ & Luxembourg & $0.2570 / 0.2354$ \\
\hline Algeria & $0.1699 / 0.1673$ & Iran & $0.1914 / 0.1939$ & New Zealand & $0.2267 / 0.2175$ \\
\hline Tanzania & $0.2152 / 0.2228$ & Iraq & $0.1115 / 0.1058$ & Papua New Guinea & $0.1174 / 0.1152$ \\
\hline Burundi & $0.1197 / 0.1174$ & Afghanistan & $0.1522 / 0.1507$ & Fiji & $0.1074 / 0.1216$ \\
\hline Cape Verde & $0.1354 / 0.1255$ & Azerbaijan & $0.1220 / 0.1214$ & Chile & $0.2075 / 0.1875$ \\
\hline Uganda & $0.1449 / 0.1470$ & Georgia & $0.1277 / 0.1331$ & Guyana & $0.1416 / 0.1444$ \\
\hline Gambia & $0.1043 / 0.0824$ & Armenia & $0.1203 / 0.1206$ & Bolivia & $0.1732 / 0.1722$ \\
\hline Togo & $0.1068 / 0.1111$ & Kazakhstan & $0.3616 / 0.3659$ & Uruguay & $0.1984 / 0.1934$ \\
\hline Rwanda & $0.1356 / 0.1313$ & Kyrgyzstan & $0.1210 / 0.1212$ & Venezuela & $0.1323 / 0.1212$ \\
\hline Morocco & $0.1804 / 0.1669$ & Tajikistan & $0.1206 / 0.1175$ & Suriname & $0.1335 / 0.1206$ \\
\hline Madagascar & $0.1834 / 0.1762$ & Uzbekistan & $0.1461 / 0.1467$ & Ecuador & $0.1303 / 0.1287$ \\
\hline Tunisia & $0.1360 / 0.1275$ & Thailand & $0.2156 / 0.2021$ & Peru & $0.1870 / 0.1844$ \\
\hline Libya & $0.1360 / 0.1356$ & Indonesia & $0.3318 / 0.3331$ & Costa Rica & $0.1501 / 0.1459$ \\
\hline Egypt & $0.1655 / 0.1542$ & Philippines & $0.1773 / 0.1717$ & Panama & $0.1269 / 0.1278$ \\
\hline Liberia & $0.0981 / 0.0941$ & Yemen & $0.1250 / 0.1034$ & Salvador & $0.1181 / 0.1116$ \\
\hline Lesotho & $0.0989 / 0.0783$ & Cyprus & $0.1701 / 0.1393$ & Dominica & $0.1269 / 0.1276$ \\
\hline Comoros & $0.0932 / 0.0973$ & Russia & $0.6280 / 0.6364$ & Trinidad and Tobago & $0.1034 / 0.0927$ \\
\hline Benin & $0.1232 / 0.1242$ & Austria & $0.2041 / 0.1868$ & Barbados & $0.1478 / 0.1301$ \\
\hline Mali & $0.2007 / 0.1994$ & Greece & $0.1754 / 0.1508$ & Cuba & $0.1140 / 0.1171$ \\
\hline Niger & $0.2333 / 0.2361$ & Poland & $0.1824 / 0.1731$ & Jamaica & $0.1019 / 0.0979$ \\
\hline Republic of Korea & $0.1933 / 0.1836$ & Serbia & $0.1230 / 0.1196$ & & \\
\hline
\end{tabular}


Figures 7 and 8 show the spatial distribution pattern of arable land investment potential in 119 countries along the BRI. The value of arable land investment potential in the countries increased in 2016 compared to 2010. Among them, the investment potential of arable land in most countries in Asia and Europe is at the upper-middle level, most of the African countries have the lower-middle level of arable land investment potential, and some countries have more significant potential. The investment potential of the American countries is at the middle-to-lower level.

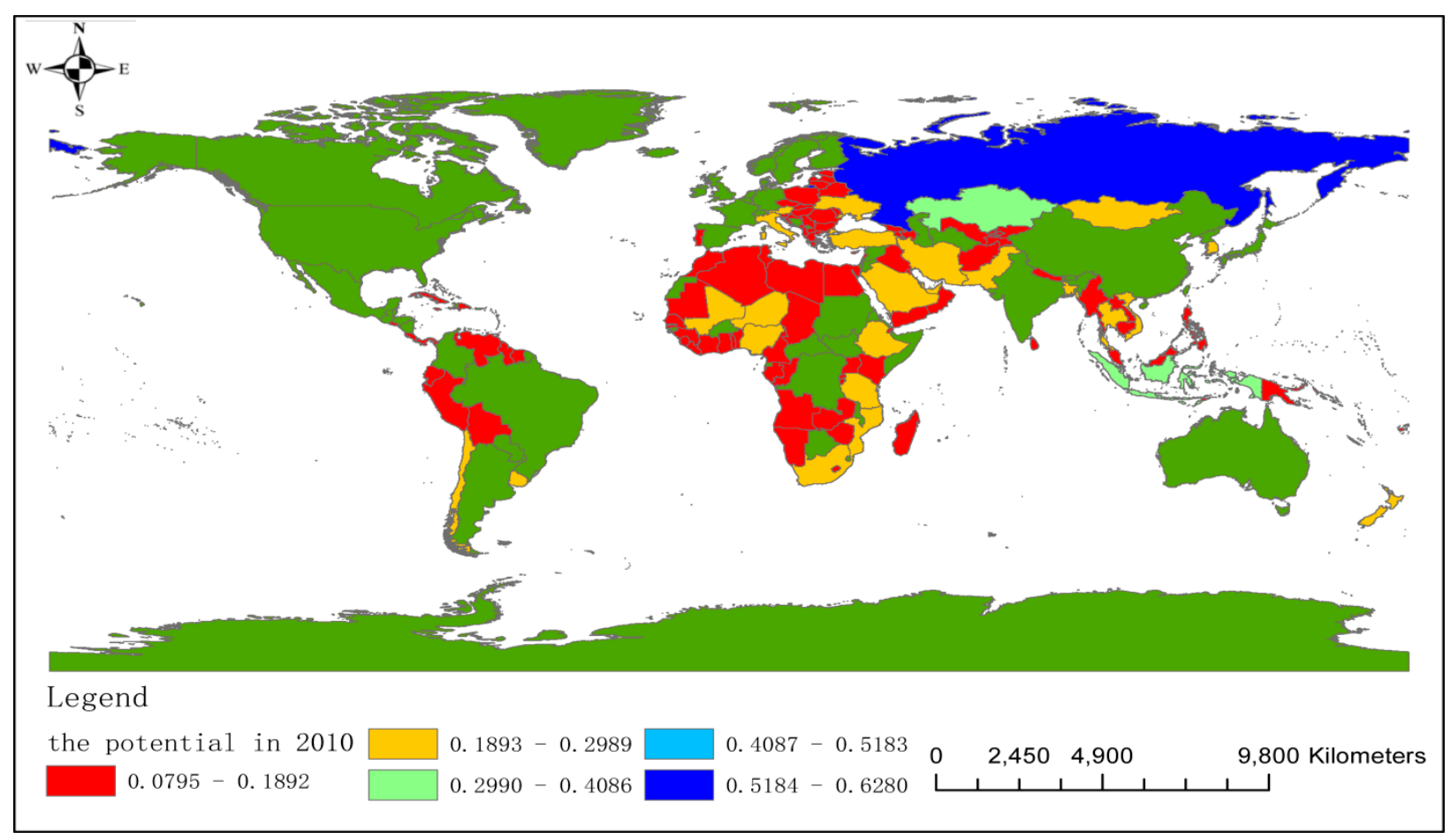

Figure 7. Distribution of arable land investment potential in the "the belt and road initiative" countries in 2010.

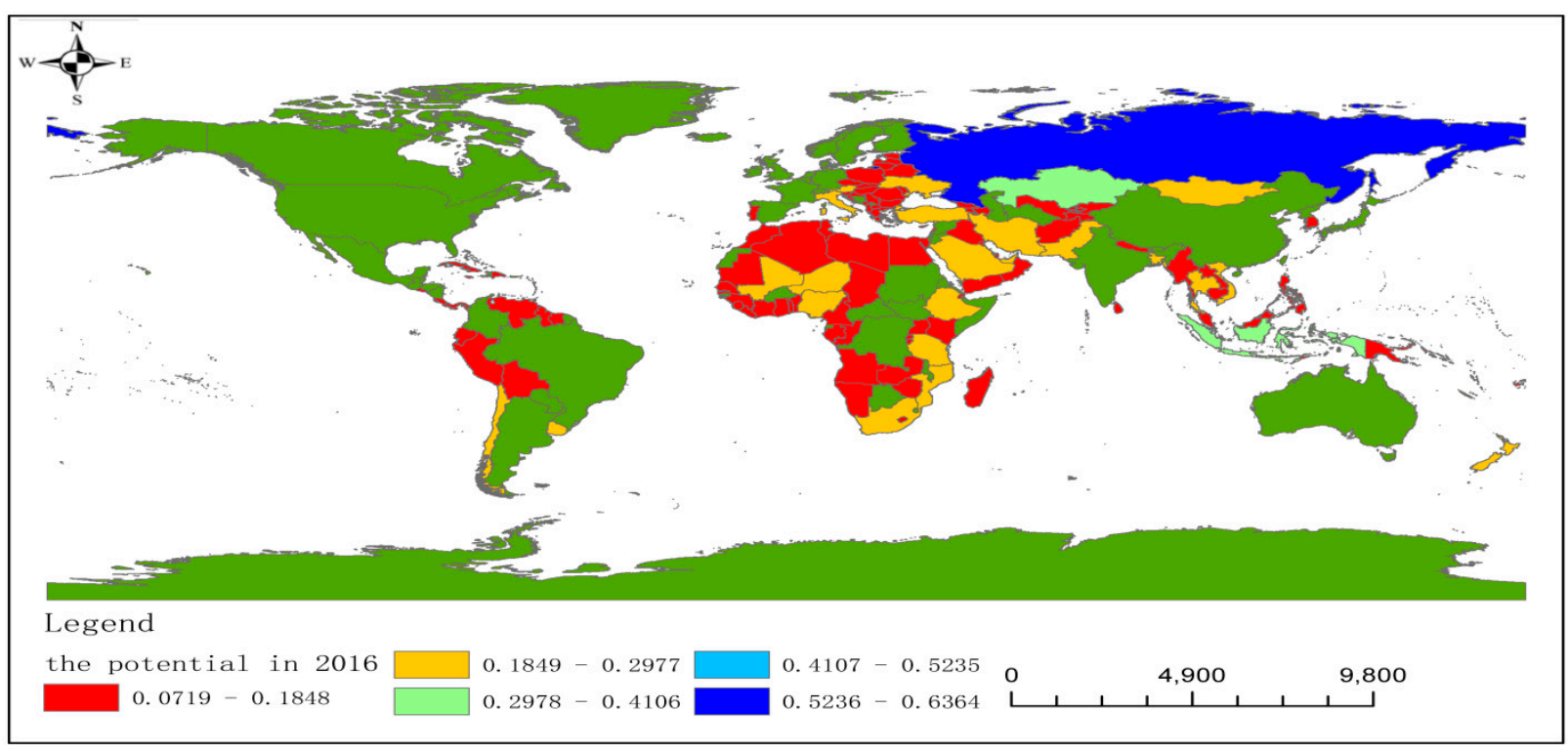

Figure 8. Distribution of arable land investment potential in the "the belt and road initiative" countries in 2016. 


\subsection{Exploratory Spatial Analysis}

With the development of overseas arable land investment markets and the expansion of inter-regional openness, the spatial linkages between arable land investment potential are becoming more significant. In order to explore the spatial dispersion and agglomeration characteristics and distribution trends of arable land investment potential in each country along the BRI, the study conducts an exploratory spatial analysis further to analyze the distribution pattern of potential in each country.

\subsubsection{Global Spatial Autocorrelation Analysis}

The section performs a global autocorrelation analysis of each country's arable land investment potential to examine the correlation and variability across regional aggregates and study the overall trend of its spatial correlation. Table 6 shows that under the spatial weight matrix of economic distance, the global Moran's I index of arable land investment potential of BRI countries is negative and passes the significance test in 2010 and 2016. Therefore, it indicates a significant negative correlation between the arable land investment potential of each country. However, the absolute values of Moran's I are smaller, and the negative correlation is relatively weaker, and the $\mathrm{Z}$ value in 2016 is more significant than that in 2010, indicating that the spatial dispersion of the investment potential of arable land in countries along the BRI has decreased by 2016. Overall, the spatial dispersion and variability of arable land investment potential in countries along the BRI are more significant than the agglomeration, which may be caused by the differences in resource endowments and other conditions.

Table 6. Moran's I index test of cultivated land investment potential index of countries along "the belt and road initiative".

\begin{tabular}{|c|c|c|c|c|c|c|c|c|c|c|}
\hline & \multicolumn{2}{|c|}{$\begin{array}{l}\text { Investment } \\
\text { Potential }\end{array}$} & \multicolumn{2}{|c|}{$\begin{array}{c}\text { Resource } \\
\text { Endowment }\end{array}$} & \multicolumn{2}{|c|}{$\begin{array}{l}\text { Production } \\
\text { Conditions }\end{array}$} & \multicolumn{2}{|c|}{$\begin{array}{c}\text { Economic } \\
\text { Level }\end{array}$} & \multicolumn{2}{|c|}{$\begin{array}{c}\text { Political } \\
\text { Environment }\end{array}$} \\
\hline & 2010 & 2016 & 2010 & 2016 & 2010 & 2016 & 2010 & 2016 & 2010 & 2016 \\
\hline Moran's I & -0.053 & -0.047 & -0.068 & -0.067 & 0.008 & 0.008 & 0.001 & -0.007 & 0.020 & 0.019 \\
\hline $\mathrm{E}(\mathrm{I})$ & -0.008 & -0.008 & -0.008 & -0.008 & -0.008 & -0.008 & -0.008 & -0.008 & -0.008 & -0.008 \\
\hline$Z$ value & -2.206 & -1.923 & -3.119 & -3.060 & 0.800 & 0.807 & 0.462 & 0.076 & 1.368 & 1.313 \\
\hline$p$ value & 0.014 & 0.027 & 0.001 & 0.001 & 0.212 & 0.210 & 0.322 & 0.470 & 0.086 & 0.095 \\
\hline
\end{tabular}

In the criterion layer, the global Moran's I index of resource endowment in 2010 and 2016 is negative and passes the significance test, indicating a significant negative correlation between the distribution of resources in countries along BRI. There are significant differences in the distribution of resources in countries with similar levels of economic development. The distribution of resources in countries along the BRI has a negative correlation, and the distribution of resources in countries with similar economic development levels is different, showing the distribution of "large, mixed and small cluster". By 2016, the absolute value of the Z-value had slightly decreased, indicating that the dispersion of the resource distribution is decreasing. The global Moran's I indices for both production conditions and political environment are positive, but the p-values are more significant than 0.05 ; therefore, the original hypothesis is accepted. It indicates that the overall spatial correlation between production conditions and the political environment in each country is not significant. However, drawing on related studies, Moran's $1>\mathrm{E}(\mathrm{I})$ and $\mathrm{Z}>0$ suggest a non-significant correlation between production conditions and the political environment in each country in space. The economic conditions Moran's I index was positive in 2010 and negative by 2016, but none of them passed the significance test, indicating that the spatial correlation of the economic conditions of each country is not significant.

\subsubsection{Local Spatial Autocorrelation Analysis}

The global spatial autocorrelation analysis reveals the overall spatial pattern of arable land investment potential in the countries along the BRI. In order to examine the local cor- 
relations of arable land investment potential in each country in more detail, to understand the spatial clustering status of high and low values of arable land investment potential in 119 countries, and to explore their local spatial variability and correlation, the article conducts a local spatial pattern analysis.

The results show that the local Moran's I index is still negative and significantly rejects the original hypothesis of "no spatial autocorrelation" for some countries, consistent with global spatial autocorrelation test results. In order to represent the test of spatial correlation more graphically, the study also describes it by drawing a scatter plot. The horizontal coordinate represents the arable land investment potential, and the vertical coordinate is the spatially lagged data of investment potential. For better understanding, the plot is divided into four quadrants. The first and third quadrants reflect local spatial positive autocorrelation, indicating $\mathrm{H}-\mathrm{H}$ agglomeration and $\mathrm{L}-\mathrm{L}$ agglomeration types. On the other hand, the second and fourth quadrants reflect local spatial negative autocorrelation, indicating $\mathrm{L}-\mathrm{H}$ and $\mathrm{L}-\mathrm{L}$ agglomeration types, denoting $\mathrm{L}-\mathrm{H}$ and $\mathrm{H}-\mathrm{L}$ are agglomeration types, respectively.

As shown in Figure 9, most countries in the two different years fall in the second, third, and fourth quadrants, further rejecting the original hypothesis that the arable land investment potential shows a random distribution in space. The countries along the BRI with high and low arable land investment potential are spatially represented by large and small clusters. However, the countries with low potential still dominate, and more countries belong to the low and high low types and are connected into pieces. Interestingly, the Moran's I value decreases from -0.053 in 2010 to - 0.047 in 2016, indicating that the spatial correlation between the investment potential of arable land in each country is weakening. In contrast, the number of countries in the first quadrant (high-high agglomeration) and the third quadrant (low-low agglomeration) decreased by 2016, validating the results of the global correlation analysis. However, Sierra Leone and Russia in the second and fourth quadrants are far from the origin, further proving that Sierra Leone's arable land investment potential is low and Russia's arable land investment potential is much higher than the other countries. In summary, the analysis shows that countries with similar arable land investment potential no longer tend to be spatially contiguous due to differences in resource endowments and policy conditions across countries. The degree of spatial dispersion is higher than the degree of spatial dispersion agglomeration.
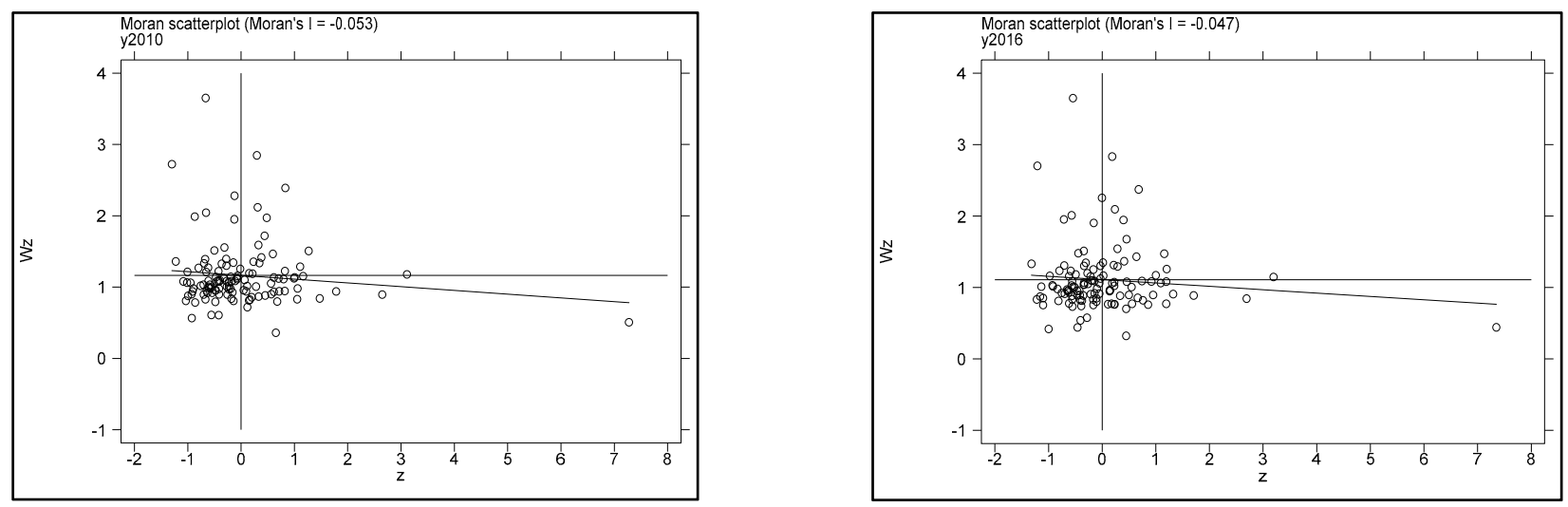

Figure 9. Moran's I scatter diagram of arable land investment potential of countries along "the belt and road initiative".

\subsubsection{Nuclear Density and Trend Surface Analysis}

In order to continue exploring the differences in the clustering of arable land investment potential over time in each country, kernel density estimates were performed for 2010 and 2016 using a kernel density function to obtain a distribution for both years. The results of kernel density estimation of arable land investment potential in countries along the BRI are shown in Figure 10. It shows that: (i) the kernel density curve did not shift significantly from 2010 to 2016, indicating that the investment potential of arable land did not change 
much in each country during the study period and remained relatively stable. (ii) There is only one peak in the graph, and the steepness of the peak in 2016 has slightly increased compared with that in 2010, indicating a polarized pattern of investment potential in arable land in countries along BRI. (iii) The investment potential of cropland in most countries is concentrated between 0.1 and 0.2 , and the trend of the wave moving to both sides is not apparent, indicating that the low investment potential of cropland in most countries will persist for a long time.

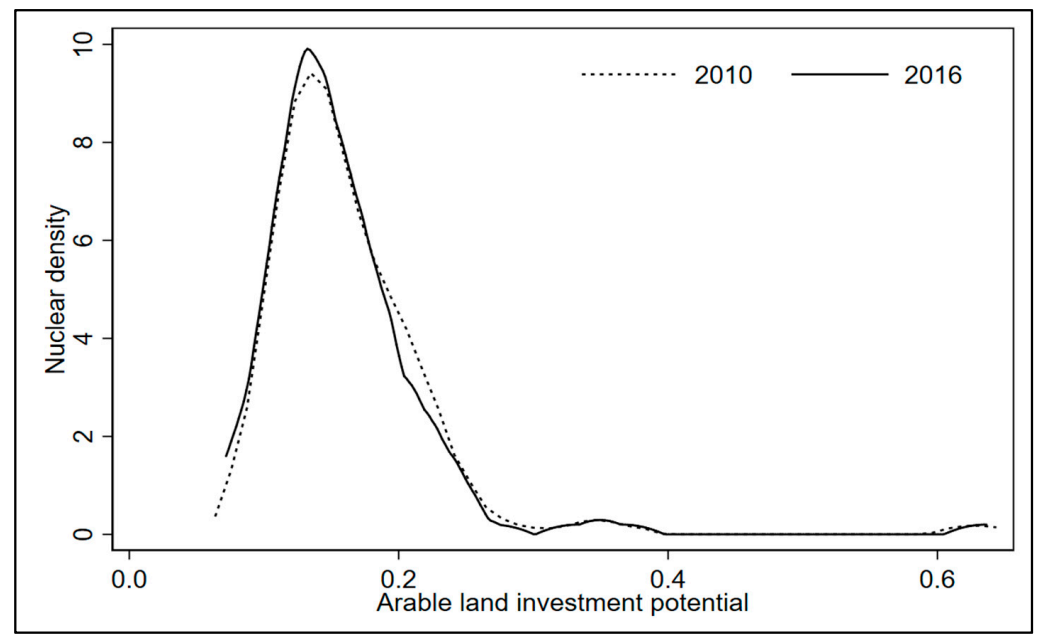

Figure 10. Kernel density estimation of arable land investment potential of countries along "the belt and road initiative".

The trend surface analysis method is used to analyze the trend characteristics and determine the distribution law and development trend. As shown in Figure 11, the arable land investment potential in 2010 and 2016 is represented by the vertical direction Zaxis, the due east direction by $\mathrm{X}$-axis, and the due north direction by Y-axis. The two trend lines are fitted lines of points in space projected to the $\mathrm{X}-\mathrm{Z}$ plane and $\mathrm{Y}-\mathrm{Z}$ plane, respectively. However, none of the trend lines parallel the $X-Y$ plane, indicating specific spatial divergence characteristics of the arable land investment potential. Overall, the investment potential of arable land in countries along the BRI is high in the east and low in the west, with a shaped divergence between the north and the south, and the difference in the north-south direction is slightly larger than the east-west direction.
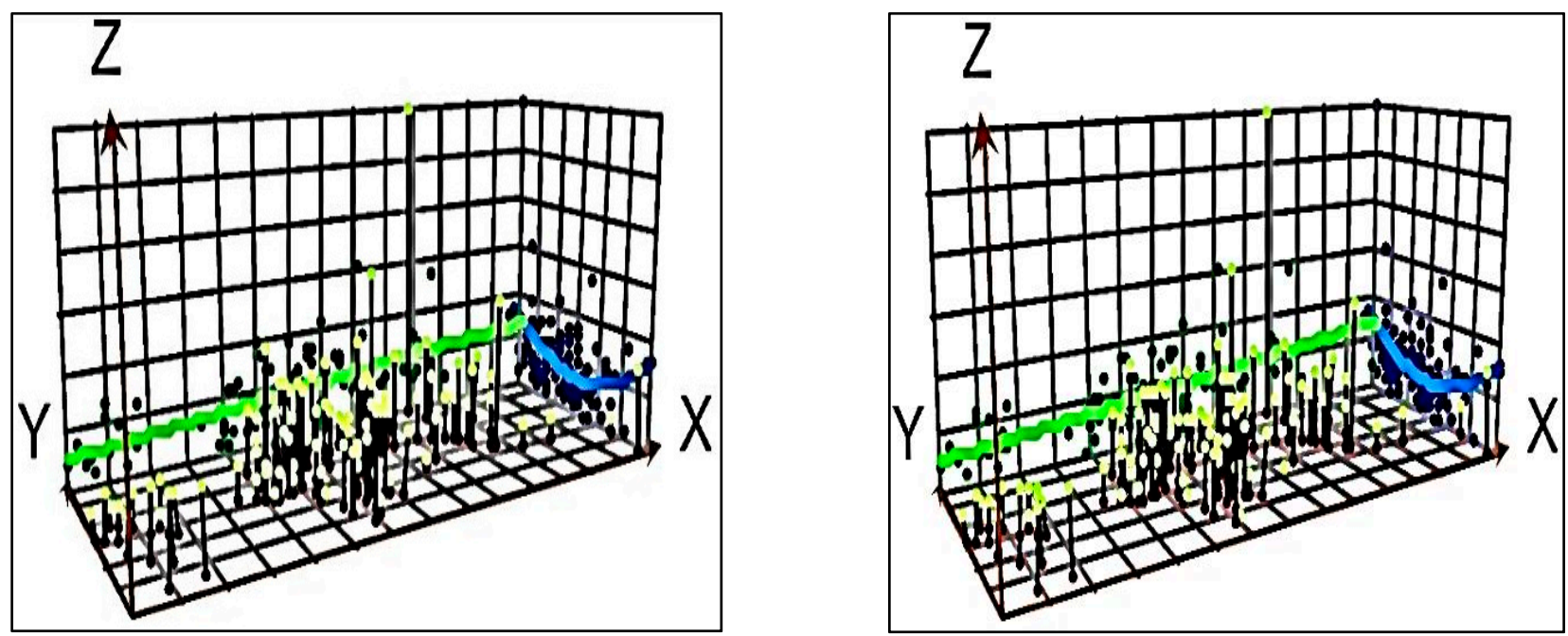

Figure 11. Trend surface analysis of arable land investment potential of countries along "the belt and road initiative". 


\section{Discussion}

For a better understanding of investment potential, countries are classified into "high potential", "average potential", and "low potential" based on the fuzzy C-mean cluster analysis. Nearly $42 \%$ of countries are classified in the "high potential" group, and more than half belongs to African and Asian region. Further, the study clusters those countries into four dimensions of the investment environment. The results show that African and Asian countries have better resource endowments and production conditions, which contribute more to the investment potential of arable land but have unstable economic conditions in political environments. European countries, in contrast, have better economic conditions and political environments but less optimistic resource endowments and production conditions. In order to obtain accurate estimates of investment potential, the entropy weighting method was applied to measure the weights of each indicator further and then calculate the investment potential of each country's arable land. The results show that resource endowment contributes the most to the investment potential of arable land with a weight of $51.76 \%$, followed by production conditions with a weight of $22.43 \%$, and the remaining two dimensions, economic conditions and political environment, contribute less to the investment potential of arable land. Moreover, by calculating the potential value of the arable land investment in each country by weighting, the potential value ranges from 0.0719 to 0.6364 in 2016, which is higher than in 2010. Most countries in Asia and Europe are in the upper-middle range of potential. Most African countries are in the lower middle class.

From the spatial pattern, the global Moran's I index results show a significant negative correlation between the spatial distribution of investment potential in arable land in countries along BRI in 2010 2016. Investment potential is more spatially discrete and heterogeneous than agglomerative, resulting in negative correlations and decreased dispersion in 2016 compared to 2010. Resource endowment also has a significant negative spatial correlation in the criterion layer, and the remaining variables have insignificant spatial correlations. The Moran's I scatterplot shows that countries with low investment potential in arable land dominate, with more contiguous countries belonging to the low-low and high-low types, and the distribution has prominent spatially non-homogeneous characteristics.

From the distribution pattern and trend, the kernel density curve shows that the investment potential of arable land in countries along the BRI has a bifurcated pattern and remains stable in the long term. Most countries will have investment potential concentrated between 0.1 and 0.2 in the long term. The trend surface shows that the spatial distribution of arable land investment potential in each country is high in the east and low in the west, with a shaped divergence in the north-south direction, and the difference in the north-south direction is more significant than that in the east-west direction.

\section{Conclusions}

Based on macro data, the study constructs a comprehensive evaluation index system of arable land investment potential of countries along the "belt and road initiative" from four distinct dimensions: resource endowment, production conditions, economic conditions, and political environment. The existing researches have not fully captured this crucial issue. More specifically, the article evaluates and measures the arable land investment potential of 119 countries along the BRI using the fuzzy C-mean cluster analysis method and entropy weight method. The spatial correlation analysis of arable land investment potential of 119 countries along the BRI in 2010 and 2016 has also been portrayed. The distribution and trend of each country's arable land investment potential are further explored by using the kernel density estimation and trend surface analysis method based on the ESDA method from the spatial and temporal perspectives. We also explore the spatial relationship of the investment potential of cultivated land in various countries and trace the changes in time and space of those potential countries. We provide an in-depth analysis of the characteristics of the investment potential of each country and provide an appropriate investment strategy for Chinese companies. 
The investment potential of arable land in BRI countries is high in the east and low in the west, with a U-shaped distribution pattern in the north and south. Chinese companies should accurately grasp each country's differences in resource endowments and production conditions when choosing a host country, give full play to regional advantages, optimize investment layout, and improve the level of investment. Moreover, they should try to choose countries in regions with more significant investment potential, such as Asia and Africa. On the one hand, Asia and Africa have better resource endowments and production conditions, but their economic and political environments are inadequate to fully use China's economic advantages to some of its potentials. Large countries make investments and complement each other's advantages to achieve a win-win effect. The more they grasp the characteristics of the investment environment, the more conducive to giving full play to regional advantages. It is conducive to optimizing the investment layout and improving the level of investment in cultivated land.

Due to negative spatial correlation, there are apparent differences in the investment potential of arable land in various countries. Therefore, it is necessary to fully consider their regional characteristics and avoid low agglomeration areas. This study can help any investors considering investing in arable land in the studied countries. Although additional investments in agriculture in developing countries by the private and the public sector should be welcome in principle, the scale, the terms, and the speed of land acquisition have provoked opposition in some target countries. The investment potential of arable land in the countries along the "belt and road" is high in the east and low in the west, with a U-shaped distribution pattern in the north and south. Therefore, the next step should be to focus on the arable land investment environment of countries in the southeast and northeast, explore existing investment cases, explore better modes of investment, and increase investment in countries with a good investment environment.

As the core data frame of the study is relatively narrowed (2010-2016), future researches should explore the investment potential with the broader timeframe. In addition, the indicator system for measuring the investment potential of cultivated land based on secondary data sources could provide a bias assumption to find the indicators of cultivated land quality, which leads to some errors in the results. Thus, it will be more interesting if future research can focus on empirical setup for crafting the indicator systems. Due to the lack of available data, land price has been omitted from the index-building. The study only studied 119 countries, and the other 19 countries' data have not been compiled as those countries' data have been restricted by their government. This is the main limitation of the study. Future research needs to include all factors that affect the investment potential of arable land into the indicator system. The trends of resource endowment, production conditions, economic conditions, and political environment should be cultured with the structural model to provide an in-depth understanding of the inner relationship. It would be of great interest to verify the methodology at a country level to specify the regional differences within one country for future studies. It would also be interesting to complement the study with environmental regulations: how and to what extent environmental regulations can impact the investment potential could be an excellent research scope.

Author Contributions: Conceptualization, Y.W. and A.S.; Methodology, Y.W., Q.W. and L.M.; Software, A.S. and L.M.; Validation, Y.W., A.S. and Q.W.; Formal analysis, A.S. and Y.W.; Investigation, Y.W. and L.M.; Resources, Y.W. and L.M.; Data curation, A.S.; Writing-original draft preparation, A.S. and Y.W.; Writing-review and editing, A.S., Y.W., and L.M.; Visualization, F.W., A.S., and L.M.; Supervision, F.W.; Project administration, Q.W. and L.M.; Funding acquisition, F.W. All authors have read and agreed to the published version of the manuscript.

Funding: This research was funded by the National Natural Science Foundation of China, grant numbers 71673222 and 72064009, the Humanities and Social Science Fund of Ministry of Education of China, grant number 15XJA790005, the China Scholarship Council Funded Project, grant number 202106300001, and the Shaanxi Provincial Key R\&D Program Project, grant number 2020KW-029. 
Institutional Review Board Statement: Ethical review and approval were waived for this study as the study does not collect any personal data of the respondents, and respondents were informed that they could opt out any time from giving a response.

Informed Consent Statement: Informed consent was obtained from all subjects involved in the study. Data Availability Statement: The data will be provided upon request by the corresponding author. Conflicts of Interest: The authors declare no conflict of interest.

\section{References}

1. Kang, S.; Hao, X.; Du, T.; Tong, L.; Su, X.; Lu, H.; Li, X.; Huo, Z.; Li, S.; Ding, R. Improving Agricultural Water Productivity to Ensure Food Security in China under Changing Environment: From Research to Practice. Agric. Water Manag. 2017, 179, 5-17. [CrossRef]

2. Li, F.; Liu, Q.; Dong, S.; Cheng, H. Agricultural Development Status and Key Cooperation Directions between China and Countries along “The Belt and Road". IOP Conf. Ser. Earth Environ. Sci. 2018, 190, 012058. [CrossRef]

3. Tian, R.; Yang, Z.; Shao, Q. China's Arable Land Investment in the "Belt and Road" Region: An Empirical Study of Overseas Arable Land Resources. Sustainability 2020, 12, 97. [CrossRef]

4. Cui, Z.; Dou, Z.; Chen, X.; Ju, X.; Zhang, F. Managing Agricultural Nutrients for Food Security in China: Past, Present, and Future. Agron. J. 2014, 106, 191-198. [CrossRef]

5. Xu, J.; Zhang, Z.; Zhang, X.; Ishfaq, M.; Zhong, J.; Li, W.; Zhang, F.; Li, X. Green Food Development in China: Experiences and Challenges. Agriculture 2020, 10, 614. [CrossRef]

6. Tortajada, C.; Zhang, H. When Food Meets BRI: China's Emerging Food Silk Road. Glob. Food Secur. 2021, 29, 100518. [CrossRef]

7. Xu, Z.; Xu, J.; Deng, X.; Huang, J.; Uchida, E.; Rozelle, S. Grain for Green versus Grain: Conflict between Food Security and Conservation Set-Aside in China. World Dev. 2006, 34, 130-148. [CrossRef]

8. Zhan, S.; Zhang, H.; He, D. China's Flexible Overseas Food Strategy: Food Trade and Agricultural Investment between Southeast Asia and China in 1990-2015. Globalizations 2018, 15, 702-721. [CrossRef]

9. Russo, A.; Cirella, G.T. Edible Green Infrastructure for Urban Regeneration and Food Security: Case Studies from the Campania Region. Agriculture 2020, 10, 358. [CrossRef]

10. Falkendal, T.; Otto, C.; Schewe, J.; Jägermeyr, J.; Konar, M.; Kummu, M.; Watkins, B.; Puma, M.J. Grain Export Restrictions during COVID-19 Risk Food Insecurity in Many Low- and Middle-Income Countries. Nat. Food 2021, 2, 11-14. [CrossRef]

11. Tarra, S.; Mazzocchi, G.; Marino, D. Food System Resilience during COVID-19 Pandemic: The Case of Roman Solidarity Purchasing Groups. Agriculture 2021, 11, 156. [CrossRef]

12. O'Hara, S.; Toussaint, E.C. Food Access in Crisis: Food Security and COVID-19. Ecol. Econ. 2021, 180, 106859. [CrossRef]

13. Zhang, J. Beyond the 'Hidden Agricultural Revolution' and 'China's Overseas Land Investment': Main Trends in China's Agriculture and Food Sector. J. Contemp. China 2019, 28, 746-762. [CrossRef]

14. Lu, J. Grounding Chinese Investment: Encounters between Chinese Capital and Local Land Politics in Laos. Globalizations 2021, 18, 422-440. [CrossRef]

15. He, M.; Huang, Z.; Zhang, N. An Empirical Research on Agricultural Trade between China and "The Belt and Road" Countries: Competitiveness and Complementarity. Mod. Econ. 2016, 7, 1671. [CrossRef]

16. Zhang, Y.; Zhang, J.-H.; Tian, Q.; Liu, Z.-H.; Zhang, H.-L. Virtual Water Trade of Agricultural Products: A New Perspective to Explore the Belt and Road. Sci. Total Environ. 2018, 622-623, 988-996. [CrossRef]

17. Yao, H.; Alhussam, M.I.; Abu Risha, O.; Memon, B.A. Analyzing the Relationship between Agricultural FDI and Food Security: Evidence from Belt and Road Countries. Sustainability 2020, 12, 2906. [CrossRef]

18. van Wesenbeeck, C.F.A.; Keyzer, M.A.; van Veen, W.C.M.; Qiu, H. Can China's Overuse of Fertilizer Be Reduced without Threatening Food Security and Farm Incomes? Agric. Syst. 2021, 190, 103093. [CrossRef]

19. Fang, L.; Shuai, L. Analysis of The Factors Affecting China's Food Security and The Countermeasures. Agric. For. Econ. Manag. 2021, 4, 21-27. [CrossRef]

20. Schweizer, D.; Walker, T.; Zhang, A. Cross-Border Acquisitions by Chinese Enterprises: The Benefits and Disadvantages of Political Connections. J. Corp. Financ. 2019, 57, 63-85. [CrossRef]

21. Shi, X.; Yao, L. Prospect of China's Energy Investment in Southeast Asia under the Belt and Road Initiative: A Sense of Ownership Perspective. Energy Strategy Rev. 2019, 25, 56-64. [CrossRef]

22. Liang, Y.; Zhou, Z.; Liu, Y. Location Choices of Chinese Enterprises in Southeast Asia: The Role of Overseas Chinese Networks. J. Geogr. Sci. 2019, 29, 1396-1410. [CrossRef]

23. Lu, X.; Li, Y.; Ke, S. Spatial Distribution Pattern and Its Optimization Strategy of China's Overseas Farmland Investments. Land Use Policy 2020, 91, 104355. [CrossRef]

24. Luo, L.; Qi, Z.; Hubbard, P. Not Looking for Trouble: Understanding Large-Scale Chinese Overseas Investment by Sector and Ownership. China Econ. Rev. 2017, 46, 142-164. [CrossRef]

25. Hussain, J.; Zhou, K.; Guo, S.; Khan, A. Investment Risk and Natural Resource Potential in "Belt \& Road Initiative" Countries: A Multi-Criteria Decision-Making Approach. Sci. Total Environ. 2020, 723, 137981. [CrossRef] 
26. Tian, R.; Yang, Z.; Shao, Q. Effects of Host Country Resource Endowment and Labor Cost on China's Investment in Overseas Cultivated Land. Environ. Sci. Pollut. Res. 2020, 27, 45282-45296. [CrossRef]

27. Böhme, M. Shared Interest or Strategic Threat? A Critical Investigation of Political Debates and Regulatory Responses to Chinese Agricultural Investment in Australia. Globalizations 2021, 18, 441-460. [CrossRef]

28. Jin, G.; Shen, K.; Jiang, Y. Does the Belt and Road Initiative Cause More Troubled Chinese Overseas Investments? Int. Rev. Econ. Financ. 2021, 72, 217-232. [CrossRef]

29. Margulis, M.E.; Porter, T. Governing the Global Land Grab: Multipolarity, Ideas, and Complexity in Transnational Governance. Globalizations 2013, 10, 65-86. [CrossRef]

30. List, J.A.; Qui, L.D. Intellectual Property Rights, Environmental Regulations, and Foreign Direct Investment. Land Econ. 2004, 80, 153-173. [CrossRef]

31. Borras, S.M. The Politics of Transnational Agrarian Movements. Dev. Chang. 2010, 41, 771-803. [CrossRef]

32. Cotula, L.; Vermeulen, S.; Mathieu, P.; Toulmin, C. Agricultural Investment and International Land Deals: Evidence from a Multi-Country Study in Africa. Food Secur. 2011, 3, 99-113. [CrossRef]

33. Arezki, R.; Deininger, K.W.; Selod, H. The Global Land Rush: Foreign Investors Are Buying up Farmland in Developing Countries. Financ. Dev. 2012, 49. [CrossRef]

34. Borras, S.M., Jr.; Edelman, M.; Kay, C. Transnational Agrarian Movements: Origins and Politics, Campaigns and Impact. J. Agrar. Chang. 2008, 8, 169-204. [CrossRef]

35. McMichael, P. Reframing Development: Global Peasant Movements and the New Agrarian Question. Can. J. Dev. Stud. Rev. Can. Détudes Dév. 2006, 27, 471-483. [CrossRef]

36. Daniel, S.; Mittal, A. The Great Land Grab: Rush for World's Farmland Threatens Food Security for the Poor. Oakl. Inst. 2009, 47, 777-780.

37. Robertson, B.; Pinstrup-Andersen, P. Global Land Acquisition: Neo-Colonialism or Development Opportunity? Food Secur. 2010, 2, 271-283. [CrossRef]

38. Löhr, D. The Driving Forces of Land Conversion. Towards a Financial Framework for Better Land Use Policy. Land Tenure J. 2010, 1, 23-34.

39. Shan, L.; Yu, A.T.W.; Wu, Y. Strategies for Risk Management in Urban-Rural Conflict: Two Case Studies of Land Acquisition in Urbanising China. Habitat Int. 2017, 59, 90-100. [CrossRef]

40. Ujunwa, A.; Okoyeuzu, C.; Igwe, A.; Ukpere, W.I. Socio-Economic Risk Factors of Foreign Land Acquisition in a Developing Country. Risk Gov. Control Financ. Mark. Inst. 2016, 6, 457.

41. Breu, T.; Bader, C.; Messerli, P.; Heinimann, A.; Rist, S.; Eckert, S. Large-Scale Land Acquisition and Its Effects on the Water Balance in Investor and Host Countries. PLOS ONE 2016, 11, e0150901. [CrossRef] [PubMed]

42. Magnan, A. Fields of Gold: Financing the Global Land Rush. J. Peasant Stud. 2021, 48, 680-683. [CrossRef]

43. Cotula, L.; vermeulen, S. Deal or No Deal: The Outlook for Agricultural Land Investment in Africa. Int. Aff. 2009, 85, 1233-1247. [CrossRef]

44. Daniel, S. Situating Private Equity Capital in the Land Grab Debate. J. Peasant Stud. 2012, 4, 23-36. [CrossRef]

45. Bekele, A.E.; Drabik, D.; Dries, L.; Heijman, W. Large-Scale Land Investments, Household Displacement, and the Effect on Land Degradation in Semiarid Agro-Pastoral Areas of Ethiopia. Land Degrad. Dev. 2021, 32, 777-791. [CrossRef]

46. Ayelazuno, J.A. Water and Land Investment in the "Overseas" of Northern Ghana: The Land Question, Agrarian Change, and Development Implications. Land Use Policy 2019, 81, 915-928. [CrossRef]

47. Chen, Y.; Li, X.; Wang, L.; Wang, S. Is China Different from Other Investors in Global Land Acquisition? Some Observations from Existing Deals in China's Going Global Strategy. Land Use Policy 2017, 60, 362-372. [CrossRef]

48. Smaller, C. A Global Thirst: How Water Is Driving the New Wave of Foreign Investment in Farmland. Int. Inst. Sustain. Dev. 2010, $5,21-45$.

49. Chuang, K.-S.; Tzeng, H.-L.; Chen, S.; Wu, J.; Chen, T.-J. Fuzzy C-Means Clustering with Spatial Information for Image Segmentation. Comput. Med. Imaging Graph. 2006, 30, 9-15. [CrossRef] [PubMed]

50. Bezdek, J.C.; Ehrlich, R.; Full, W. FCM: The Fuzzy c-Means Clustering Algorithm. Comput. Geosci. 1984, 10, 191-203. [CrossRef]

51. Panda, S.; Sahu, S.; Jena, P.; Chattopadhyay, S. Comparing Fuzzy-C Means and K-Means Clustering Techniques: A Comprehensive Study. In Proceedings of the Advances in Computer Science, Engineering \& Applications, New Delhi, India, 25-27 May 2012; Wyld, D.C., Zizka, J., Nagamalai, D., Eds.; Springer: Berlin/Heidelberg, Germany, 2012; pp. 451-460.

52. Pal, N.R.; Bezdek, J.C.; Hathaway, R.J. Sequential Competitive Learning and the Fuzzy C-Means Clustering Algorithms. Neural Netw. 1996, 9, 787-796. [CrossRef]

53. Bezdekt, J.C. Cluster Validity with Fuzzy Sets. J. Cybern. 1973, 3, 58-73. [CrossRef]

54. Zhu, L.; Chung, F.-L.; Wang, S. Generalized Fuzzy C-Means Clustering Algorithm With Improved Fuzzy Partitions. IEEE Trans. Syst. Man Cybern. Part B Cybern. 2009, 39, 578-591. [CrossRef]

55. Nayak, J.; Naik, B.; Behera, H.S. Fuzzy C-Means (FCM) Clustering Algorithm: A Decade Review from 2000 to 2014 . In Proceedings of the Computational Intelligence in Data Mining_Volume 2, Odisha, India, 5-6 December 2015; Jain, L.C., Behera, H.S., Mandal, J.K., Mohapatra, D.P., Eds.; Springer: New Delhi, India, 2015; pp. 133-149.

56. Fan, J.-L.; Zhen, W.-Z.; Xie, W.-X. Suppressed Fuzzy C-Means Clustering Algorithm. Pattern Recognit. Lett. 2003, 24, 1607-1612. [CrossRef] 
57. Wang, X.; Wang, Y.; Wang, L. Improving Fuzzy C-Means Clustering Based on Feature-Weight Learning. Pattern Recognit. Lett. 2004, 25, 1123-1132. [CrossRef]

58. Palarea-Albaladejo, J.; Martín-Fernández, J.A.; Soto, J.A. Dealing with Distances and Transformations for Fuzzy C-Means Clustering of Compositional Data. J. Classif. 2012, 29, 144-169. [CrossRef]

59. Bertsekas, D.P. Constrained Optimization and Lagrange Multiplier Methods; Academic Press: Cambridge, MA, USA; ISBN 1-48326047-X.

60. Ahn, B.S. Compatible Weighting Method with Rank Order Centroid: Maximum Entropy Ordered Weighted Averaging Approach. Eur. J. Oper. Res. 2011, 212, 552-559. [CrossRef]

61. Zhu, Y.; Tian, D.; Yan, F. Effectiveness of Entropy Weight Method in Decision-Making. Math. Probl. Eng. 2020, 2020 , e3564835. [CrossRef]

62. Sepehri, M.; Malekinezhad, H.; Hosseini, S.Z.; Ildoromi, A.R. Assessment of Flood Hazard Mapping in Urban Areas Using Entropy Weighting Method: A Case Study in Hamadan City, Iran. Acta Geophys. 2019, 67, 1435-1449. [CrossRef]

63. Anselin, L. Interactive Techniques and Exploratory Spatial Data Analysis. Reg. Res. Inst. Work. Pap. 1996, 3, 12-19.

64. De Jong, P.; Sprenger, C.; Van Veen, F. On Extreme Values of Moran's I and Geary's c. Geogr. Anal. 1984, 16, 17-24. [CrossRef]

65. Papalia, R.B.; Bertarelli, S. The Role of Local Agglomeration Economies and Regional Characteristics in Attracting FDI: Italian Evidence. Int. J. Econ. Bus. 2009, 16, 161-188. [CrossRef]

66. Zhong, Y.; Jiang, M. Spatial Structure of FDI Distribution in Jiangxi Province. Territ. Nat. Resour. Study 2010, 1, 14-29.

67. Alamá-Sabater, L.; Heid, B.; Jiménez-Fernández, E.; Márquez-Ramos, L. What Drives Interdependence of FDI among Host Countries? The Role of Geographic Proximity and Similarity in Public Debt. Econ. Model. 2016, 58, 466-474. [CrossRef]

68. Hui, E.C.M.; Liang, C. Spatial Spillover Effect of Urban Landscape Views on Property Price. Appl. Geogr. 2016, 72, 26-35. [CrossRef]

69. Zhang, R.; Andam, F.; Shi, G. Environmental and Social Risk Evaluation of Overseas Investment under the China-Pakistan Economic Corridor. Environ. Monit. Assess. 2017, 189, 253. [CrossRef]

70. Botev, Z.I.; Grotowski, J.F.; Kroese, D.P. Kernel Density Estimation via Diffusion. Ann. Stat. 2010, 38, 2916-2957. [CrossRef]

71. Chorley, R.J.; Haggett, P. Trend-Surface Mapping in Geographical Research. Trans. Inst. Br. Geogr. 1965, 47-67. [CrossRef]

72. Gano, S.; Kim, H.; Brown, D. Comparison of Three Surrogate Modeling Techniques: Datascape, Kriging, and Second Order Regression. In Proceedings of the 11th AIAA/ISSMO Multidisciplinary Analysis and Optimization Conference, Portsmouth, VA, USA, 6-8 September 2006.

73. Häberli, C. Foreign Direct Investment in Agriculture: Land Grab or Food Security Improvement. Econ. Anal. Int. Law 2014, 2 283-303. [CrossRef]

74. Visser, O.; Spoor, M. Land Grabbing in Post-Soviet Eurasia: The World's Largest Agricultural Land Reserves at Stake. J. Peasant Stud. 2011, 38, 299-323. [CrossRef]

75. Ndikumana, L.; Sarr, M. Capital Flight and Foreign Direct Investment in Africa: An Investigation of the Role of Natural Resource Endowment; WIDER Working Paper: Helsinki, Finland, 2016; ISBN 92-9256-101-4.

76. Rogmans, T.; Ebbers, H. The Determinants of Foreign Direct Investment in the Middle East North Africa Region. Int. J. Emerg. Mark. 2013, 8, 240-257. [CrossRef]

77. Songwe, V.; Deininger, K. Foreign Investment in Agricultural Production: Opportunities and Challenges. Agric. Rural Dev. Notes 2009, 4, 13-45.

78. Bevan, A.A.; Estrin, S. The Determinants of Foreign Direct Investment into European Transition Economies. J. Comp. Econ. 2004, 32, 775-787. [CrossRef]

79. Deseatnicov, I.; Akiba, H. Exchange Rate, Political Environment and FDI Decision. Int. Econ. 2016, 148, 16-30. [CrossRef]

80. Kok, R.; Ersoy, B.A. Analyses of FDI Determinants in Developing Countries. Int. J. Soc. Econ. 2009. [CrossRef]

81. Nath, R.; Luan, Y.; Yang, W.; Yang, C.; Chen, W.; Li, Q.; Cui, X. Changes in Arable Land Demand for Food in India and China: A Potential Threat to Food Security. Sustainability 2015, 7, 5371-5397. [CrossRef]

82. Diao, X.; Hazell, P.; Thurlow, J. The Role of Agriculture in African Development. World Dev. 2010, 38, 1375-1383. [CrossRef]

83. Izakian, H.; Abraham, A. Fuzzy C-Means and Fuzzy Swarm for Fuzzy Clustering Problem. Expert Syst. Appl. 2011, 38, 1835-1838. [CrossRef]

84. Lu, Z.; Huang, X. Application of Fuzzy C-Mean Clustering Based on Multi-Polar Fuzzy Entropy Improvement in Dynamic Truck Scale Cheating Recognition. Int. J. Comput. Intell. Syst. 2020, 13, 1590-1597. [CrossRef] 